OPEN ACCESS

Edited by:

Christian Grenz,

Mediterranean Institute of

Oceanography, France

Reviewed by:

Lyndon Mark DeVantier,

Coral Reef Research and Museum of

Tropical Queensland, Australia

Marcos Mateus,

Universidade de Lisboa, Portugal

${ }^{*}$ Correspondence:

Pia Kegler

piakegler@gmx.de

Specialty section:

This article was submitted to Marine Ecosystem Ecology,

a section of the journal

Frontiers in Marine Science

Received: 13 December 2016 Accepted: 04 August 2017

Published: 22 August 2017

Citation:

Kegler P, Kegler HF, Gärdes A, Ferse SCA, Lukman M, Alfiansah YR,

Hassenrück $C$ and Kunzmann $A$ (2017) Bacterial Biofilm Communities and Coral Larvae Settlement at Different Levels of Anthropogenic Impact in the Spermonde Archipelago, Indonesia. Front. Mar. Sci. 4:270. doi: 10.3389/fmars.2017.00270

\section{Bacterial Biofilm Communities and Coral Larvae Settlement at Different Levels of Anthropogenic Impact in the Spermonde Archipelago, Indonesia}

\author{
Pia Kegler ${ }^{1 *}$, Hauke F. Kegler ${ }^{2}$, Astrid Gärdes ${ }^{2}$, Sebastian C. A. Ferse ${ }^{1}$, \\ Muhammad Lukman ${ }^{3}$, Yustian R. Alfiansah ${ }^{2,4}$, Christiane Hassenrück ${ }^{5}$ and \\ Andreas Kunzmann ${ }^{1}$
}

\begin{abstract}
${ }^{1}$ Department of Ecology, Leibniz Centre for Tropical Marine Research, Bremen, Germany, ${ }^{2}$ Department of Biogeochemistry and Geology, Leibniz Centre for Tropical Marine Research, Bremen, Germany, ${ }^{3}$ Department of Marine Science, Center for Marine, Coastal and Small Islands Research, Hasanuddin University, Makassar, Indonesia, ${ }^{4}$ Research Center for Oceanography, Indonesian Institute of Sciences (LIPI), Jakarta, Indonesia, ${ }^{5}$ HGF MPG Joint Research Group for Deep-Sea Ecology and Technology, Max Planck Institute for Marine Microbiology, Bremen, Germany
\end{abstract}

Populations on small islands surrounded by coral reefs often heavily depend on the services provided by these reefs. The health and recovery of reefs are strongly influenced by recruitment of coral larvae. Their settlement relies on cues such as those emitted from bacterial communities forming biofilms on reef surfaces. Environmental conditions can change these bacterial community compositions (BCC) and may in turn affect settlement of coral larvae. At three small inhabited islands in the Spermonde Archipelago, Indonesia, with different distance from the mainland, BCC and coral recruitment were investigated on artificial ceramic tiles after 2-8 weeks exposure time and on natural reef substrate. Water parameters showed a clear separation between inshore and near-shore/mid-shelf sites, with distinct benthic communities at all three sites. No coral recruitment was observed at the inshore site with highest natural and anthropogenic stressors. At the other two sites coral recruitment occurred on natural surfaces (recruits per $100 \mathrm{~cm}^{2}: 0.73 \pm 1.75$ near-shore, $0.90 \pm 1.97$ mid-shelf), but there was no significant difference between the two sites. On artificial substrates coral recruitment differed between these two sites, with tile orientation and with exposure time of the tiles in the reef. The most abundant bacteria on both substrates were Gammaproteobacteria, Alphaproteobacteria, and Cyanobacteria. BCC was strongly correlated with water quality and significant differences in BCC between the inshore site and near-shore/mid-shelf were found. On artificial substrates there was a significant difference in BCC also with exposure time in the reef. Our study highlights the value of taking both BCC and coral recruitment into account, in addition to the environmental conditions, when considering the recovery potential of coral reefs.

\footnotetext{
Keywords: coral reefs, coral recruitment, settlement cues, illumina sequencing, water quality
} 


\section{INTRODUCTION}

Coral reefs worldwide are declining due to a multitude of anthropogenic stressors that frequently act in combination (Burke et al., 2012). In tropical countries, reefs often surround small islands along the coasts, providing essential livelihoods for the inhabitants of these islands (Cinner, 2014), while being subjected to combined influences from the mainland and the islands themselves (Baum et al., 2015).

The Spermonde Archipelago in South Sulawesi, Indonesia, was selected as a case study area. Several dozen, mostly inhabited small islands fringed by coral reefs provide the unique possibility to study reefs subjected to various natural and anthropogenic influences, mainly related to the city of Makassar with 1.5 million inhabitants (Sawall et al., 2012, 2013; Polónia et al., 2015), resulting in an environmental gradient with increasing distance from the city (Cleary et al., 2005; Polónia et al., 2015; Teichberg et al., 2017).

Water quality and benthic community composition as foundations for the overall reef status differ markedly between islands within the Archipelago (see Polónia et al., 2015). Over the past decades studies in Spermonde have shown declining coral cover, habitat degradation, and reefs impacted by blast fishing activities (Edinger et al., 1998; Pet-Soede and Erdmann, 1998).

Scleractinian corals provide the foundation and threedimensional structure of the reef (Veron, 2000), leading to high diversity and functionality of the ecosystem (Stanley, 2003; Munday, 2004). Coral reefs around the world are threatened due to a multitude of mostly anthropogenic disturbances (Carpenter et al., 2008; Halpern et al., 2008; Burke et al., 2012). Sexual recruitment via pelagic coral larvae is essential for the recovery of coral reefs (Harrison, 2011; Sawall et al., 2013). It can replenish coral populations in destroyed reef areas and can lead to an enhanced fitness of reef communities through adaptation of coral genotypes (Harrison, 2011). Knowledge on coral reproduction and recruitment is therefore critical in understanding how different stressors may affect reef populations and can be used for effective coral reef management (Richmond and Wolanski, 2011).

Two terms that are often used in parallel in the context of coral reproduction are settlement and recruitment. Settlement is the phase of attachment of the pelagic larvae onto benthic substrates (Keough and Downes, 1982). Recruitment is the entire process from larval to the juvenile stage, including the planktonic stage, the settlement, and the post-settlement survival after onset of skeletal accretion during metamorphosis (Keough and Downes, 1982). Settlement of coral larvae depends on specific and very complex environmental stimuli that relay information about the respective benthic habitat (Ritson-Williams et al., 2009). Besides physical cues such as light and depth (Price, 2010), settlement-inhibiting or inducing chemical cues emanating from biological sources appear to be the most relevant (Harrison, 2011). The metamorphosis to the juvenile stage also depends on environmental stimuli and is not necessarily linked to settlement (Ritson-Williams et al., 2009). In the context of biological cues for settlement and metamorphosis, bacteria, especially those in biofilms, play an important role in emitting cues for coral larvae (Hadfield, 2011).

Bacteria and other microorganisms form biofilms, covering most surfaces in the sea (Qian et al., 2003). Settlement of invertebrate larvae is assumed to be triggered by bacteria in biofilms (Huggett et al., 2006; Sneed et al., 2014). Reports of interactions between larvae and bacteria exist for many marine invertebrates such as sponges, echinoderms, bryozoans, ascidians, crustaceans, and corals (Hadfield, 2011). For a large range of coral species crustose coralline algae (CCA) and their associated bacteria have been recorded to induce both settlement and metamorphosis of larvae (Heyward and Negri, 1999; Price, 2010; Webster et al., 2011). Each CCA species hosts a very unique bacterial community on its surface (Sneed et al., 2015). One genus of bacteria mentioned frequently in the context of inducing larval settlement and metamorphosis is Pseudoalteromonas (Negri et al., 2001; Hadfield, 2011; Tran and Hadfield, 2011). Tetrabromopyrrole (TBP), a metabolite produced by strains of this genus, was identified as an inducer of metamorphosis, although in many cases no settlement occurred (Tebben et al., 2011; Sneed et al., 2014). While Tebben et al. (2015) conclude from their findings that it is not bacteria but CCA that produce the essential settlement cues, coral larvae also settle on surfaces not covered by CCA, indicating the importance of bacterial biofilms (Webster et al., 2004).

There are reports that no single bacterial strain, but rather the combination of several species within the biofilm community on reef surfaces is of importance for larval settlement (Qian et al., 2003; Chung et al., 2010). The bacterial community composition (BCC) in biofilms can shift rapidly with environmental conditions due to their short generation times (Bourne and Webster, 2013), as demonstrated for altered temperature and salinity (Lau et al., 2005), or eutrophication (Meyer-Reil and Köster, 2000). Sawall et al. (2012) reported shifts in bacterial communities on artificial surfaces at higher nutrient levels, from autotrophic to heterotrophic and sulfur-reducing bacteria. They found that the community depended significantly on the orientation and exposure time of surfaces and recorded higher operational taxonomic unit (OTU) numbers on artificial surfaces in eutrophied near-shore reefs. In cases where bacterial community structure in biofilms is altered, the emitted settlement cues from the bacteria can change. Lau et al. (2005) recorded a significant response of barnacle larvae to biofilms altered by high temperature, while settlement of polychaete larvae was more affected by changes in salinity. The microbial community associated with a tropical CCA species shifted significantly when subjected to high temperature, with an increase in Bacteroidetes and reduction of Alphaproteobacteria, which in turn led to a reduction of the ability to induce metamorphosis in coral larvae (Webster et al., 2011).

Although the important role of bacteria in the settlement process of coral larvae is widely accepted, the underlying mechanisms and key players remain poorly understood. It is still unclear which bacteria are affecting settlement of coral larvae and what BCCs favor or alter the settlement behavior. Furthermore, very little information exists on the influence of environmental conditions on BCC (Qian and Dahms, 2009), 
and on how such changes will affect larval settlement. Previous authors were able to identify changes in bacterial communities (Qian et al., 2003; Sawall et al., 2012), but unable to specifically identify the altered groups of bacteria within their samples due to methodological limitations. However, determining the taxa most affected by environmental changes would provide insight into the implications of bacterial community changes for larval settlement.

The aim of the current study in the Spermonde Archipelago, Indonesia, was to determine coral recruitment and BCC at three sites exposed to different levels of anthropogenic impact. Next generation sequencing was applied to investigate how bacterial biofilm communities differ with increasing distance from the mainland, and which environmental factors influence BCC. The hypotheses were that (I) the three investigated sites would display distinct patterns in water quality and benthic community composition reflecting different levels of anthropogenic impact, (II) BCC and coral recruitment would be different on natural substrate among the sites, (III) BCC and coral recruitment would further differ depending on exposure time, set-up and orientation of artificial substrates, and (IV) there would be no difference in BCC and coral recruitment between natural and artificial substrates. A further question was how space and time influence settlement patterns on artificial settlement substrates.

\section{MATERIALS AND METHODS}

\section{Study Area}

The study was conducted in the Spermonde Archipelago in southern Sulawesi, Indonesia in close vicinity to the large urban area of Makassar (see Figure 1). Sampling took place between April and June 2014, between the wet NW monsoon (Dec-Feb) and the dry SE monsoon (June-Sept) in this area (Sawall et al., 2013). Three islands exposed to different levels of anthropogenic impact, due to varying distance from Makassar, were selected for this study. These islands were Lae-Lae (LL, "inshore," $\sim 1$ $\mathrm{km}$ from Makassar, S $05^{\circ} 08^{\prime}, \mathrm{E} 119^{\circ} 23^{\prime}$ ), Barrang Lompo (BL, “near-shore," $11 \mathrm{~km}$ from Makassar, S $\left.05^{\circ} 03^{\prime}, \mathrm{E} 119^{\circ} 19^{\prime}\right)$, and Badi (BD, “mid-shelf," $19 \mathrm{~km}$ from Makassar, S $04^{\circ} 58^{\prime}$, E $119^{\circ} 17^{\prime}$ ). The islands have been the subject of previous studies (Sawall et al., 2013; Plass-Johnson et al., 2015, 2017; Teichberg et al., 2017). All islands are located on the continental shelf, fringed with coral reefs, and exposed to similar oceanographic conditions in terms of currents and wave action. Sampling at all islands took place at the north-western side for standardization. All islands are inhabited, with the lowest population density on the mid-shelf island (BD) with $\sim 190$ people per ha (total of 1,680, BPS Kota Makassar, 2010), intermediate on the near-shore island (BL) with $\sim 200$ people per ha $(4,200$ in total, BPS Kota Makassar, 2010) and highest on the inshore island (LL) with $\sim 220$ people per ha (total of 1,600, BPS Kota Makassar, 2010).

For in situ determinations of environmental parameters, coral recruitment and bacterial communities on natural reef substrate three $50 \mathrm{~m}$ transects were surveyed at each site once during the study period. The transects were installed parallel to the shore between 3.5 and $5.5 \mathrm{~m}$ water depth, chosen due to the high number of hard corals at this depth.

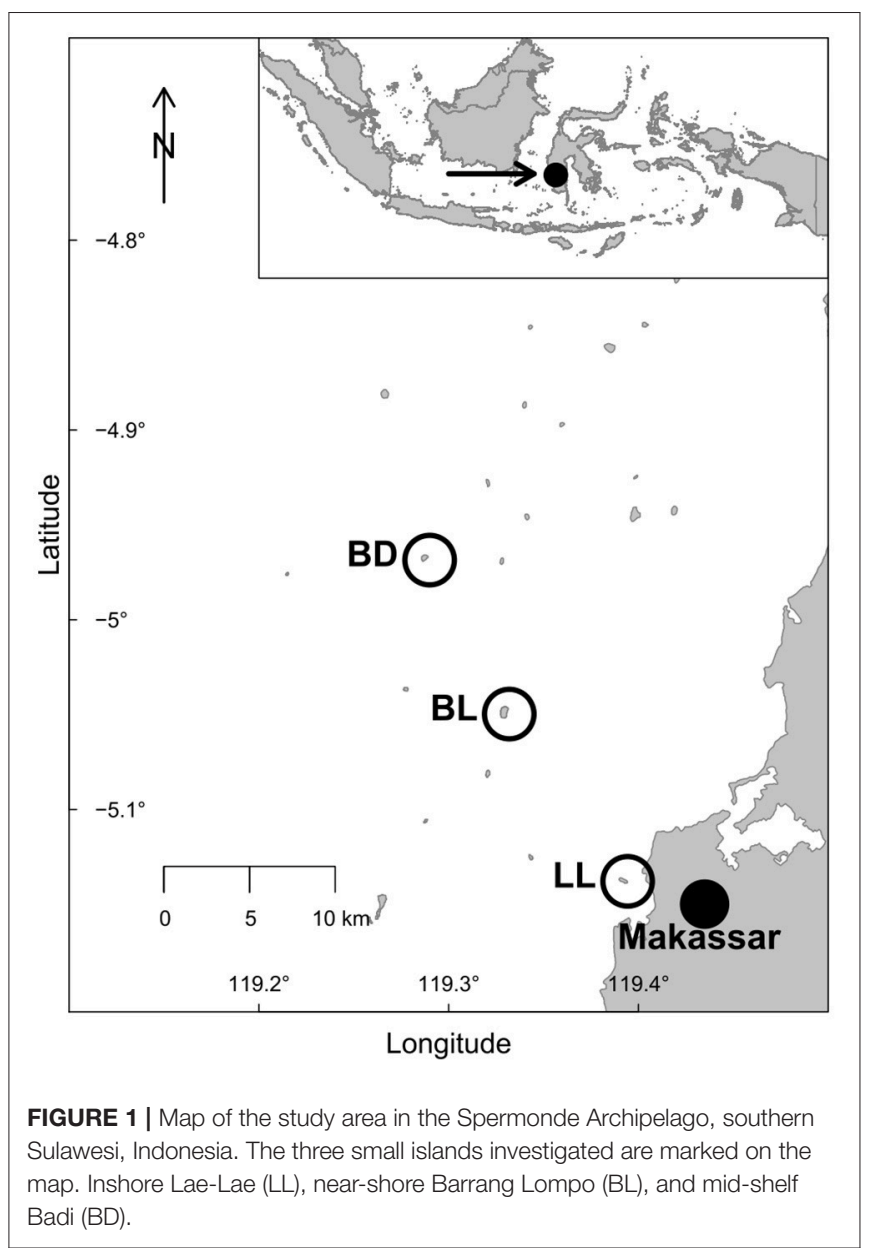

\section{Environmental Parameters}

Physio-chemical water parameters (salinity, temperature, $\mathrm{pH}$, chlorophyll a concentration, dissolved oxygen concentration, and turbidity) were collected using an Eureka 2 Manta multiprobe (Eureka Environmental Engineering, Texas, USA) for 20-30 min during each sampling and during the transect work (a total of five times at each site during the 8 week sampling period). Water samples for chemical parameters were collected in six replicates, each at a depth of $5 \mathrm{~m}$, about $1 \mathrm{~m}$ above the reef, using a $5 \mathrm{~L}$ Niskin bottle (HydroBios, Kiel, Germany). Samples were stored in the dark and transported to the laboratory at Barrang Lompo for immediate analysis.

For inorganic nutrient analysis (combined nitrate and nitrite $\mathrm{NO}_{\mathrm{x}}$, phosphate $\mathrm{PO}_{4}$, and silicate $\mathrm{Si}$ ) $50 \mathrm{~mL}$ of each sample were filtered directly on the boat through a $0.7 \mu \mathrm{m}$ syringe filter and poisoned with $200 \mu \mathrm{L}$ of a $3.5 \mathrm{~g} / 100 \mathrm{~mL} \mathrm{HgCl}_{2}$ solution. The samples were stored at $-20^{\circ} \mathrm{C}$ and transported back to the Leibniz Centre for Tropical Marine Research (ZMT), Germany for further analysis using a continuous flow analyzer (Flowsys by Unity Scientific, Brookfield, USA).

For measurements of dissolved organic carbon (DOC), $30 \mathrm{~mL}$ samples were filtered through $0.45 \mu \mathrm{m}$ pore $\mathrm{GF} / \mathrm{F}$ filters (Whatman GF/F, GE Healthcare, Pittsburgh, USA) and acidified 
with concentrated $\mathrm{HCl}$ ( $\mathrm{pH}$ below 2). Analysis took place at the ZMT, Germany with high-temperature oxic combustion (HTOC) method using a TOC-VCPH TOC analyzer (Shimadzu, Mandel, Canada). For calibration and quality control artificial seawater standards (Hansell laboratory, RSMAS University Miami, USA) and ultrapure water blanks were used.

Suspended particulate matter (SPM) was measured as dry mass on pre-combusted GF/F filters before and after filtration of a known volume of water sample (2-3 L). Weight of the filters was determined using a precision balance (ME 36S, Satorius, Göttingen, Germany) after drying the filters for $24 \mathrm{~h}$ at $40^{\circ} \mathrm{C}$.

\section{In situ Surveys and Benthic Transects}

Benthic community composition was determined once during the study period along three transects per site. Along the transects $50 \times 50 \mathrm{~cm}$ quadrats $(n=25$ for each transect) were photographed every $2 \mathrm{~m}$ alternating to the left and right. Analysis of these pictures was performed with Coral Point Count with Excel extensions (CPCe, version 4.1, Kohler and Gill, 2006) with 50 random points per picture. Eleven major categories were differentiated based on English et al. (1997). Main live categories included non-Acroporid corals, Acroporid corals, soft corals, coralline algae, macroalgae, turf, others, and unknown live, while non-living categories were substrate, dead coral, and equipment (frame of the quadrat or shadow). All hard corals were further subcategorized depending on morphology type.

Coral recruitment on natural reef substrate along all transects was determined during night dives (starting at 18:00), using fluorescence census techniques (Baird et al., 2006; SchmidtRoach et al., 2008). A $20 \times 20 \mathrm{~cm}$ quadrat was placed within a $2 \mathrm{~m}$ belt from the transect, wherever the substrate was suitable for settlement (i.e., not on live corals and sand patches, $n=10$ for each transect), and checked with a fluorescence dive light (Bluestar and GoBe, Nightsea, Bedford, USA) and a yellow filter. The number of coral recruits within the quadrat was recorded. For this study all young corals with diameters between 0.3 and $3.0 \mathrm{~cm}$ were counted as recruits, presuming that at this size they had passed the first critical post-settlement mortality phase (Arnold et al., 2010).

To assess the BCC on natural reef substrate, small rocks of approx. the same size, and covered with some crustose coralline algae were retrieved from the reef from the center of each transect. The surface of each rock was scraped with a scalpel immediately after the respective dive and the material stored in $2 \mathrm{~mL}$ Eppendorf tubes and preserved with $\sim 1.5 \mathrm{~mL}$ of RNAlater (Ambion, Texas, USA). Samples were stored in the dark and transported back to the laboratory where they were frozen at $-20^{\circ} \mathrm{C}$ until further analysis.

\section{Settlement Tiles}

For the analysis of coral larvae settlement and BCC on artificial substrates, ceramic settlement tiles were submerged on metal frames at each site ( $n=3$ per site). The frames were placed on sand patches in close proximity to live corals, separated by $\sim 5 \mathrm{~m}$ from another and at an angle of $\sim 30^{\circ}$ to reduce covering of the tiles by sediments (English et al., 1997). Ceramic settlement tiles glazed on one side and bare on the other were mounted in pairs on the frames, with the glazed sides facing each other, leaving a small gap of $0.5 \mathrm{~cm}$ (Maida et al., 1994). Each frame held 16 tile pairs. Four pairs from each frame were sampled every 2 weeks during the 8 weeks sampling campaign. For logistic reasons the samplings at the near-shore (BL) and mid-shelf $(\mathrm{BD})$ took place on the same day, followed by sampling inshore (LL) the following day.

After each sampling the tiles were transported to the laboratory at Barrang Lompo in clean individual zip-lock bags. After determination of the recruit numbers, two of the four tile pairs from each frame were chosen to be sampled for bacterial community composition. All organic material from a $1 \mathrm{~cm}$ wide patch on the side of each of those tiles (containing no coral recruits) was scraped off with a scalpel. The obtained organic material was rinsed into Eppendorf cups using $\sim 1.5 \mathrm{~mL}$ of RNAlater (Ambion, Texas, USA). The samples were frozen at $-20^{\circ} \mathrm{C}$ until further analysis.

After sampling all tiles were bleached in a 5\% sodium hypochloride solution for $12-24 \mathrm{~h}$ and subsequently dried in the sun. All coral skeletons on the tiles were marked and numbered before photographs of all tiles and individual skeletons were taken for identification. Tiles were cross-checked with the fluorescence photographs and locations where coral recruits were noted before, but no skeleton was found, were marked as well. Recruits were identified to the family level according to Babcock et al. (2003).

\section{Molecular Analysis of Bacterial Communities}

All frozen samples for bacterial analysis were transported to the ZMT in Germany. DNA was extracted for 70 samples using the MoBio PowerSoil ${ }^{\circledR}$ DNA Isolation Kit according to the manufacturer's instructions (MoBio Laboratories Inc., Carlsbad, CA, USA). DNA concentrations were measured and checked for purity before extracts were sent to LGC Genomics (Berlin, Germany) for PCR and Illumina sequencing.

DNA sequences of the V3-V4 hypervariable region of the $16 S$ rRNA gene were obtained from paired-end Illumina MiSeq amplicon sequencing at LGC Genomics (Berlin, Germany) with the primer set S-D-Bact-0341-b-S-17/S-D-Bact-0785-a-A21 (Klindworth et al., 2013). Following the removal of the primers by LGC Genomics the sequences were quality trimmed with a sliding window of $4 \mathrm{bp}$ and an average quality of 12 using the program Trimmomatic (v.0.33, Bolger et al., 2014). Forward and reverse reads for each sample were merged using PEAR (v.0.96, Zhang et al., 2014). The overlap was set to $10 \mathrm{bp}$ with a minimum and maximum length of the merged reads of 350 and $500 \mathrm{bp}$, respectively. The quality of the merged reads was checked using the application FastQC (v.0.11.3, Andrews, 2011) before the DNA sequence information was extracted for further processing using BBMap (v.35.43, Bushnell; https://sourceforge. net/projects/bbmap/). The sequences were de-replicated and clustered into OTUs using the fastidious algorithm of swarm (v.2.1.2, Mahé et al., 2014) with a cutoff between heavy and light amplicons of three. A representative sequence of each OTU was used for the taxonomic classification using SINA (SILVA 
Incremental Aligner v.1.2.11, Pruesse et al., 2012) based on the Silva 119 database (Quast et al., 2013). Unwanted lineages (such as Archaea, chloroplasts, and mitochondria) were removed from the dataset and samples with fewer than 500 sequences were excluded from the dataset for the analysis.

All original sequence data from this study are available at the European Nucleotide Archive (ENA) under the accession number PRJEB18599.

\section{Data Analysis}

Differences in environmental parameters between islands were analyzed using Kruskal-Wallis tests with post-hoc multiple pairwise comparisons (Siegel and Castellan, 1988).

Benthic communities and coral morphologies were tested for differences among sites using PERMANOVA. ANOSIM tests were used to assess the pairwise dissimilarity in benthic communities between sites. $P$-values of all multiple pairwise comparisons were adjusted using the false discovery rate (fdr) correction method by Benjamini and Hochberg (1995). Alpha diversity of benthic communities was calculated based on the inverse Simpson and Shannon diversity (see Morris et al., 2014). Differences in alpha diversity were calculated using ANOVA with TukeyHSD post-hoc tests.

To examine differences in the number of coral recruits on natural substrates and on artificial substrates, generalized linear mixed modeling with the AD Builder platform (glmmADMB, Fournier et al., 2012) was applied. Differences between natural and artificial substrates were assessed using generalized linear modeling analysis.

Alpha diversity (based on inverse Simpson and Shannon diversity) of the microbial communities was assess after repeated random subsampling to the same number of sequences per sample. For beta diversity analysis, the dataset was pruned by removing all OTUs that were not present more than once or with a minimum of two sequences in at least one sample. This reduced the number of OTUs within the dataset by $97 \%$, while retaining more than $59 \%$ of sequences per sample and retaining the significance of the original dataset (Mantel statistic $p=0.001$, $r=0.91$ ). Testing of the effect of environmental factors on BCC on natural substrate, between reef and tiles, as well as on tiles was done using PERMANOVA. To determine which factors resulted in the difference between sites, pairwise ANOSIM tests were applied. Differences in BCC were further analyzed with ALDEx2 (Fernandes et al., 2014) to identify differentially abundant OTUs (selected at a parametric significance threshold of 0.05) between conditions. Occurrence of bacteria classes containing potentially settlement inducing bacteria strains (PSIB, Huggett et al., 2006; Tebben et al., 2011; Tran and Hadfield, 2011; Sharp and Ritchie, 2012; Sneed et al., 2014) was recorded and correlation of most abundant bacteria and PSIB to environmental parameters determined using Pearson correlation and visualized in a heatmap.

All statistical analyses were performed in R ( $\mathrm{R}$ v.3.0.2, R Core Team, 2016, using R Studio v.0.98.1056) with the packages vegan (Oksanen et al., 2016), pgirmess (Giraudoux, 2016), glmmADMB (Fournier et al., 2012), lme4 (Bates et al., 2015), and gplots (Warnes et al., 2016).

\section{RESULTS}

\section{Environmental Parameters}

Among the measured environmental parameters significant differences between the three islands were found for chlorophyll a (Chl. a), SPM, and the nutrient parameters $\mathrm{NO}_{\mathrm{x}}, \mathrm{PO}_{4}$, and $\mathrm{Si}$ (Table 1). Multiple pairwise comparisons showed that differences were mainly between the inshore site (LL) and either one, or both of the sites further out on the shelf. $\mathrm{NO}_{\mathrm{x}}$ differed only between mid-shelf (BD) and inshore (LL), SPM differed only between near-shore (BL) and inshore (LL), while significant differences in $\mathrm{PO}_{4}, \mathrm{Si}$, and $\mathrm{Chl}$. a concentration were observed between inshore (LL) and both of the other islands. No significant differences in environmental parameters were found between near-shore (BL)

TABLE 1 | Environmental parameters at the three islands.

\begin{tabular}{|c|c|c|c|c|c|c|c|}
\hline & $n$ & Inshore (LL) & Near-shore (BL) & Mid-shelf (BD) & \multicolumn{3}{|c|}{ Kruskal-Wallis } \\
\hline $\mathrm{pH}$ & 5 & $8.06 \pm 0.03$ & $8.09 \pm 0.05$ & $8.06 \pm 0.04$ & 0.85 & 2 & 0.653 \\
\hline Salinity & 5 & $33.36 \pm 0.64$ & $33.33 \pm 0.75$ & $33.32 \pm 0.98$ & 0.05 & 2 & 0.977 \\
\hline $\mathrm{HDO}$ (mg/L) & 5 & $5.65 \pm 0.33$ & $6.35 \pm 0.53$ & $5.73 \pm 0.63$ & 5.1 & 2 & 0.078 \\
\hline $\mathrm{NO}_{x}(\mu \mathrm{M})$ & 5 & $0.21 \pm 0.02 \mathrm{a}$ & $0.48 \pm 0.06_{a b}$ & $0.71 \pm 0.09_{b}$ & 15.16 & 2 & $0.001^{*}$ \\
\hline $\mathrm{PO}_{4}(\mu \mathrm{M})$ & 5 & $0.18 \pm 0.01 a$ & $0.11 \pm 0.01_{b}$ & $0.12 \pm 0.01_{b}$ & 11.84 & 2 & $0.003^{\star}$ \\
\hline $\mathrm{Si}(\mu \mathrm{M})$ & 5 & $2.76 \pm 0.27 \mathrm{a}$ & $4.51 \pm 0.48_{b}$ & $4.44 \pm 0.58_{b}$ & 11.8 & 2 & $0.003^{\star}$ \\
\hline Chl. a ( $\mu \mathrm{g} / \mathrm{L})$ & 5 & $0.73 \pm 0.77 \mathrm{a}$ & $0.04 \pm 0.03 b$ & $0.02 \pm 0.01 \mathrm{~b}$ & 11.66 & 2 & $0.003^{*}$ \\
\hline SPM (mg/L) & 6 & $7.76 \pm 0.79 a$ & $2.85 \pm 1.12_{b}$ & $5.18 \pm 1.12 \mathrm{ab}$ & 14 & 2 & $0.001^{*}$ \\
\hline
\end{tabular}

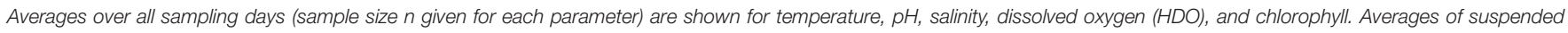

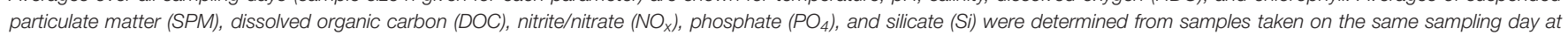

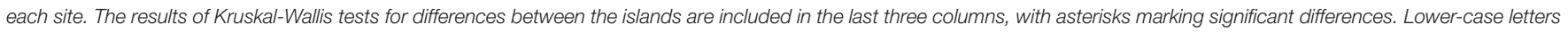
indicate significant differences based on multiple pairwise comparisons. 
and mid-shelf (BD) islands despite the closer proximity of the near-shore island (BL) to the mainland and Makassar, and the higher population density compared to the mid-shelf island (BD).

\section{Benthic Community}

There was a significant difference in benthic community structure (Figure 2) between all three sites [PERMANOVA, $\left.F_{(2,6)}=24.60, p=0.004\right]$. Pairwise ANOSIM tests revealed that the largest difference was between the inshore (LL) and mid-shelf (BD) sites and the smallest difference between nearshore (BL) and mid-shelf (BD). The most dominant group inshore (LL) was turf algae (44.0\%), with some macroalgae (9.7\%), and soft corals (5.6\%) and only few live hard corals (6.3\% non-Acropora and $0.1 \%$ Acropora). With increasing distance from the shore, live coral cover increased, while turfs decreased. Near-shore (BL) live hard coral cover was $27.4 \%$ (non-Acropora and 0.1\% Acropora) and only $3.7 \%$ were covered by turf algae. $57.1 \%$ of the reef was bare substrate. The most dominant group at the mid-shelf (BD) was live corals (38.4\%) including a large number of Acroporids (20.0\%). Only 35.9\% were composed of bare substrate.

Alpha diversity of benthic communities was assessed by inverse Simpson and Shannon diversity. Inverse Simpson diversity was lowest (i.e., highest diversity) at the near-shore site (BL) with 2.4 and was 2.9 for inshore (LL) and 3.1 for mid-shelf (BD), with a significant difference only between near-shore and mid-shelf [ANOVA, $F_{(2,6)}=7.73, p=022$, TukeyHSD, $p<0.05$ ]. Shannon diversity was 1.3 for inshore (LL), 1.2 for near-shore (BL), and 1.3 for mid-shelf (BD), with a significant difference only between inshore and near-shore [ANOVA, $F_{(2,6)}=7.05, p$ $=027$, TukeyHSD, $p<0.05]$. There was no significant difference in either of the two diversity indices between the inshore (LL) and mid-shelf (BD) sites.

There was a significant difference also in distribution of coral morphologies at the three sites [PERMANOVA, $F_{(2,6)}=11.18$, $p=0.001]$. Distributions (see Figure S1) were similar between the inshore (LL) and near-shore (BL) sites with mostly massive corals ( $>50 \%$ of total coral cover) and only few other morphology types [encrusting and tabular inshore (LL) and branching and submassive near-shore (BL)]. The range of coral morphologies at the mid-shelf site (BD) was much higher, with branching Acropora as the most abundant morphology type (28.4\%), followed by other branching corals $(17.8 \%)$, but many other morphologies were also present (encrusting, foliose, massive, submassive, and tabular).

\section{Coral Recruitment}

During the 2 month sampling period no hard coral recruitment was recorded at the inshore site (LL). At this site young recruits $(<3 \mathrm{~cm})$ occurred neither on natural reef substrates nor on settlement tiles. Recruitment of coral larvae was however recorded for both of the other sites (BL and $\mathrm{BD})$. On natural reef substrate at the near-shore reef (BL) $2.9 \pm 1.7$ hard coral recruits $(<3 \mathrm{~cm})$ were counted per $20 \times 20 \mathrm{~cm}$ quadrat $(0.73$ \pm 0.44 recruits per $100 \mathrm{~cm}^{2}$ ), at the mid-shelf (BD) numbers were slightly higher with $3.6 \pm 2.0$ per quadrat $(0.90 \pm 0.49$ recruits per $100 \mathrm{~cm}^{2}$ ). There were no significant differences between coral recruits on natural substrate between the two sites (glmmADMB).

A total of 824 coral recruits were found on artificial settlement tiles at both sites with recruits on natural substrate. 95.6\%

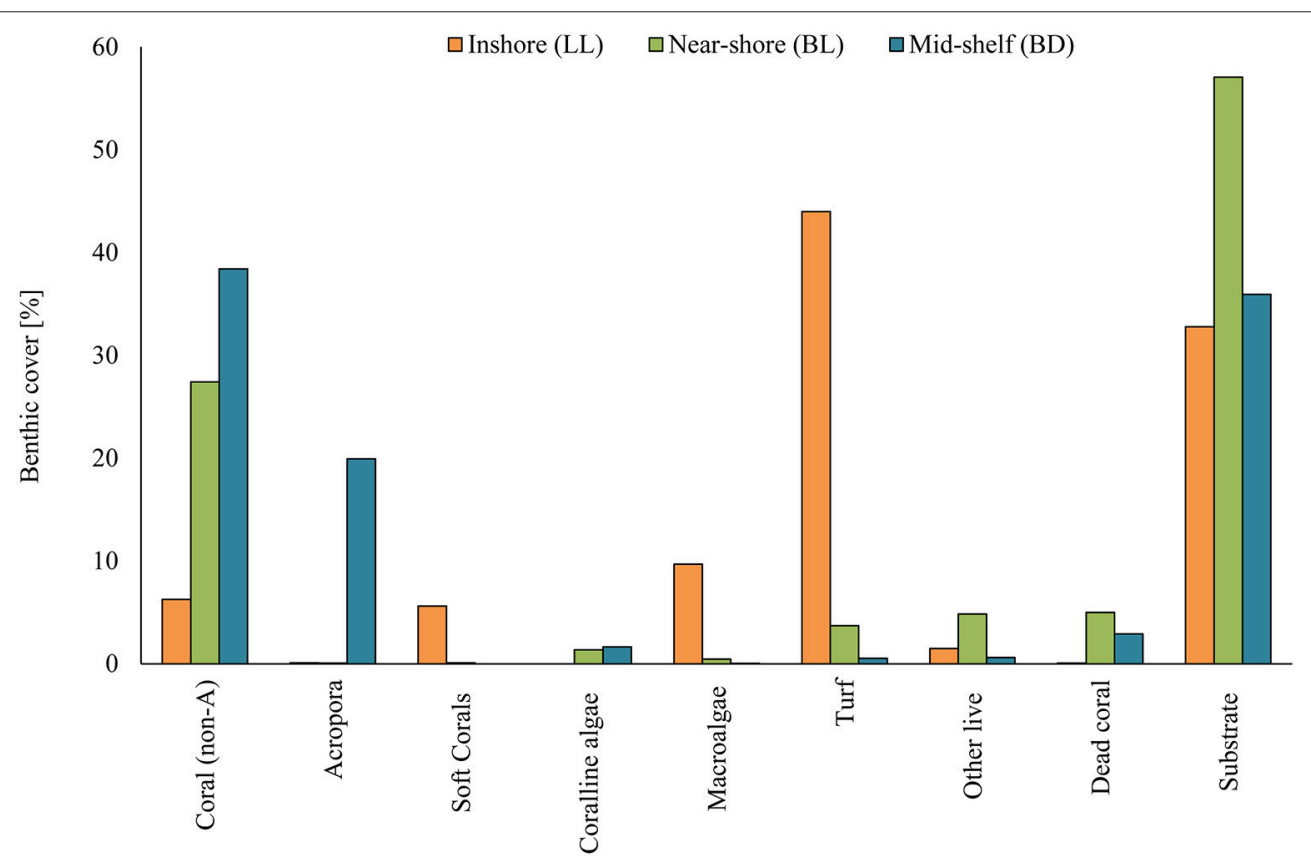

FIGURE 2 | Benthic community composition at the three sites: inshore (LL), near-shore (BL), and mid-shelf (BD). Live categories include Coral (non-Acropora hard corals), Acropora, soft corals, crustose coralline algae, turf algae, and others. Dead coral and bare substrates (sand, rock, rubble) complete the cover as non-living categories. 
of recruits were found on surfaces facing down $(65 \%$ on the lower tile, $30.6 \%$ on the upper tile; Figure 3). Recruits never settled on the upper tiles facing up, so that this side was excluded from statistical modeling analyses. $81.9 \%$ of the recruits that were identified on the settlement tiles were Pocilloporidae, 2.4\% Acroporidae and $0.7 \%$ other families. At the near-shore site $(\mathrm{BL})$ there was no difference between recruitment on natural and artificial substrates (glm modeling, $p$ $>0.05$ ), while at the mid-shelf site (BD) there were significantly lower recruit numbers on natural reef substrates compared to the lower tiles facing up $(p=0.001)$ and down $(p=$ $0.030)$.

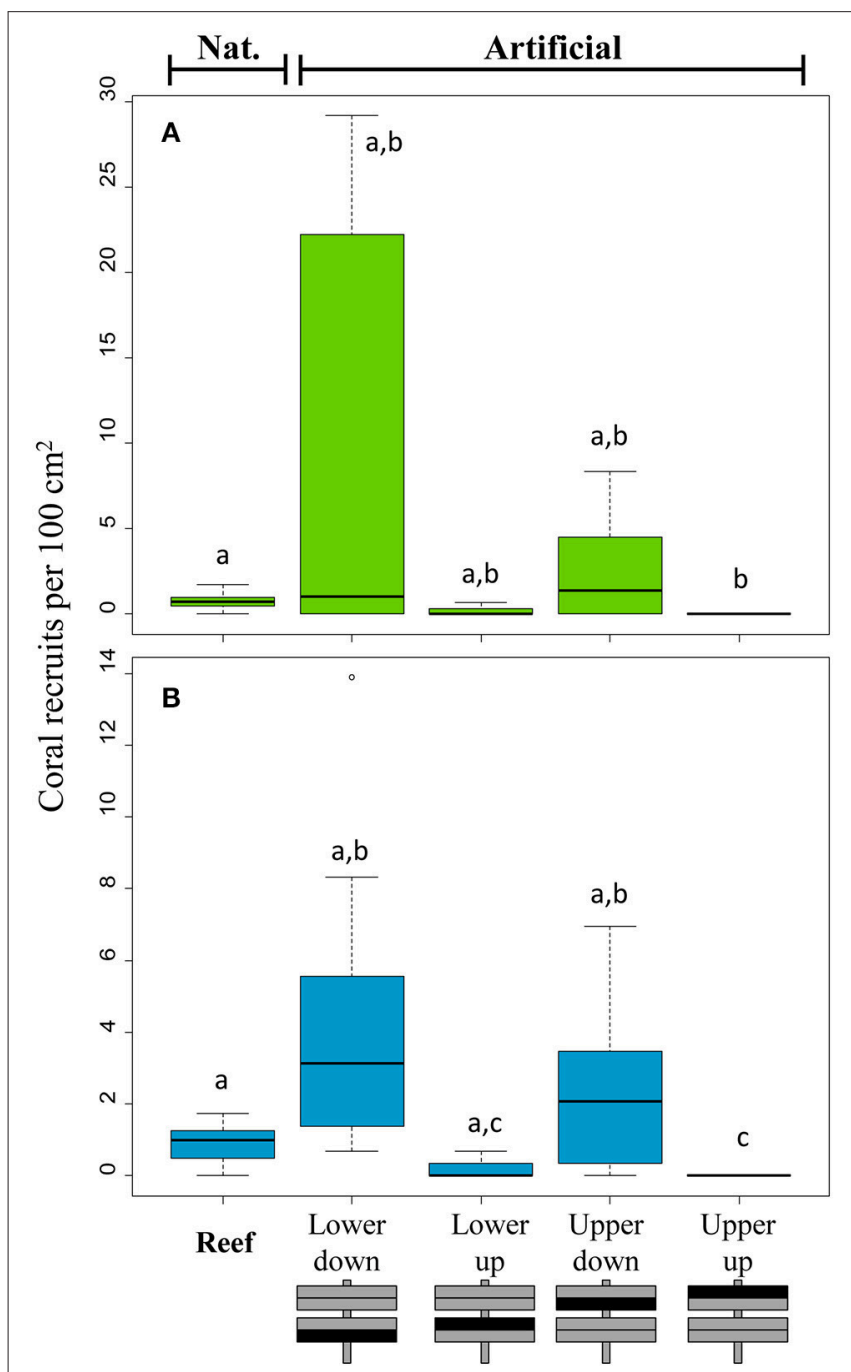

FIGURE 3 | Coral recruitment on natural reef and artificial substrates.

(A) shows recruit numbers at the near-shore $(B L),(B)$ recruit numbers at the mid-shelf (BD) site. The first box plot in each graph shows the number of recruits on natural reef substrate, the other four show the number of recruits after 8 weeks of exposure in the reef on different surfaces of artificial ceramic tiles with an upper and lower tile either facing down or up. Lower case letters indicate significance results from Kruskal Wallis multiple pairwise comparisons performed separately for each site.
Over the course of the study different temporal settlement patterns were observed at the near-shore (BL) and mid-shelf (BD) sites. At the mid-shelf site (BD) the number of coral recruits on the tiles increased with exposure time (Figure 4), while at the near-shore site $(\mathrm{BL})$ most recruits settled on the tiles during the first 2 weeks of the sampling period. Afterwards, the numbers decreased for the following 6 weeks with the exception of one of the three sampling frames, where the number of coral recruits remained the same throughout the sampling period.

Generalized linear mixed models revealed a significant effect of surface orientation and sampling site on the number of recruits on the artificial tiles by site $(z=4.71, p=2.5 \mathrm{e}-06)$, where the

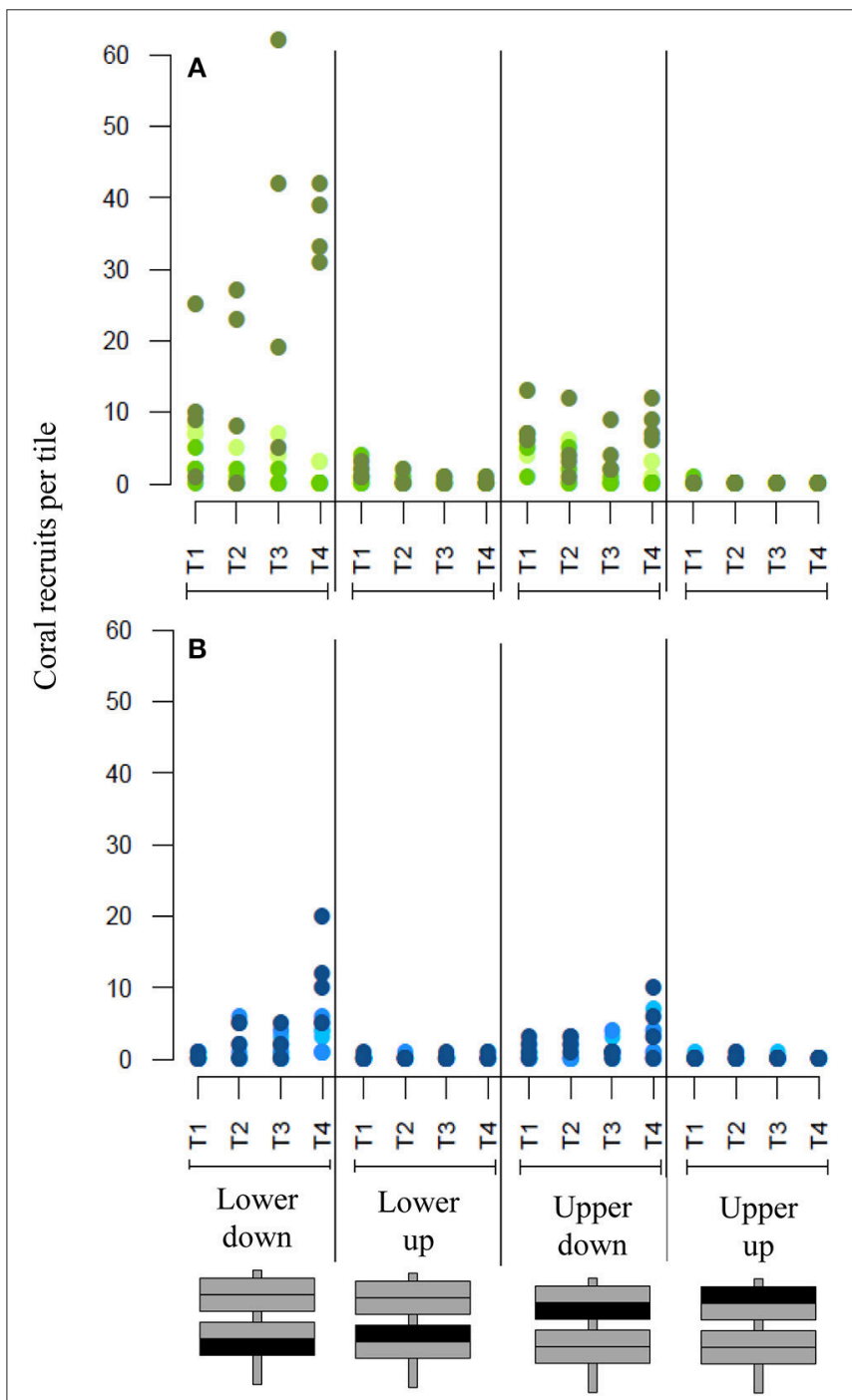

FIGURE 4 | Temporal settlement pattern of coral recruits on artificial tiles. (A) shows recruit numbers at the near-shore site $(B L),(B)$ at the mid-shelf site (BD). T1 to T4 represent the different sampling times, T1 $=2$ weeks, T2 $=4$ weeks, T3 $=6$ weeks, T4 $=8$ weeks. Recruit numbers are organized per surface orientation (upper and lower tile sides facing either up or down as indicated on the schematic). Different colors indicate measurements from the three different experimental frames. 
lower tile facing down was significantly different from the lower tile facing up $(z=-3.58, p<0.001)$, but not from the upper tile facing down $(z=1.30, p=0.195)$. Further there was a significant effect of sampling time between the number of recruits within the first 2 weeks and all of the following sampling times (to 4 weeks $z$ $=-3.38, p<0.001$, to 6 weeks $z=-3.63, p<0.001$, to 8 weeks $z=-5.99, p=2.1 \mathrm{e}-09$ ).

\section{Bacterial Communities}

There was no significant difference in alpha diversity of bacterial communities on natural reef substrate. At the inshore site (LL) diversity indices were 218.22 and 6.00 , at the near-shore site (BL) 392.37 and 6.15, and at the mid-shelf site (BD) 358.50 and 6.09 , respectively for inverse Simpson and Shannon diversity. The most abundant bacterial classes on natural reef substrates at all three sites were Alphaproteobacteria, Cyanobacteria, and Gammaproteobacteria (Figure 5). There were significant differences in BCC on natural substrate between the three sites [PERMANOVA, $R^{2}=0.34, F_{(2,6)}=1.52, p=0.002$ ]. The mid-shelf (BD) community was characterized by higher numbers of Alphaproteobacteria than the other islands, but less Gammaproteobacteria, while the inshore island (LL) had the highest abundance of Cyanobacteria and the near-shore site (BL) the highest number of Gammaproteobacteria. While the replicate samples for bacterial communities on reef substrate from inshore (LL) and mid-shelf (BD) were quite similar to one another, there was higher variability in the samples from near-shore (BL) (Figure 6).

To determine bacteria that had the largest influence on these differences between sites, a differential abundance analysis was performed. Differentially abundant OTUs between sites belonged mostly to the Cyanobacteria (Leptolyngbya, Lyngbya, Phormidium, Pleurocapsa, and members of Subsection II and III), Alphaproteobacteria (Anderseniella, Thalassospira and several members of the Rhodospirillacaea) as well as Cytophagia (Flammeovirgayeae) and Flavobacteria (Flavobacteriaceae and Muricauda). Most of these OTUs were found in higher numbers at the inshore site (LL) or at the mid-shelf site (BD), while they were either absent or present in lower numbers at the near-shore site (BL; Figure S2).

There was no significant difference in BCC in the reef and on artificial tiles after 8 weeks exposure at the near-shore site (BL). However, significant differences were found at both of the other islands (PERMANOVA, $p<0.05$, Table 2).

On the artificial ceramic tiles the same most abundant groups were found as on natural substrate (i.e., Gammaproteobacteria, Alphaproteobacteria, and Cyanobacteria, see Figure 7 and Figure S4). However, there was a higher abundance of Alphaproteobacteria on artificial substrates inshore and higher abundance of Gammaproteobacteria mid-shelf, which was in contrast to the abundances of these groups on natural substrate. Significant effects on BCC were found due to site, exposure time in the reef, surface orientation, and the interaction between exposure time and surface orientation (Table 3). Pairwise ANOSIM tests showed that the differences were mainly due to a difference in BCC on tiles from the inshore site (LL) compared to the others, while no significant differences were found between mid-shelf (BD) and near-shore (BL). This difference was mainly due to a large number of Gammaproteobacteria (esp. Vibrio) that were present in higher numbers at the near-shore (BL) and midshelf (BD) sites (see Figure S3). The largest difference among surface orientation was between the lower tile facing down and the upper exposed tile (upper tile facing up).

Several bacteria were identified in the samples, that were affiliated with taxa that can potentially induce settlement in invertebrate species (Figure 8, see Table S1 for entire list). On natural reef substrate most of these potentially settlement inducing bacteria (PSIB) were found at the near-shore site (BL) with these bacteria contributing on average $8.7 \pm 9.6 \%$ to the community. At the inshore site (LL) $2.5 \pm 1.0 \%$ and at the midshelf site (BD) $1.6 \pm 0.9 \%$ of the bacteria were PSIB. Highest number of Pseudoalteromonas were found at the near-shore site (BL) and lowest in the reef at the mid-shelf site (BD). The abundance of PSIB on artificial substrates was higher than on natural substrates. The numbers of PSIB on the lower artificial ceramic tile surfaces facing down differed both from the reef and between 2 and 8 week exposure times. After 2 weeks, the highest total number of PSIB was detected at the near-shore site (BL, $22.7 \%$ ), and the lowest at the inshore site (LL, 4.2\%). Six weeks later the number of PSIB at the inshore site (LL) increased to $13.6 \pm 14.3 \%$, and at the mid-shelf site (BD) from $10.3 \%$ after2 week exposure to $30.4 \pm 12.5 \%$ after 8 weeks. In contrast, the number of PSIB at the near-shore site (BL) decreased between the 2 and 8 week samplings from $22.7 \%$ to a final value of $6.4 \pm 1.8 \%$. On settlement tiles the highest number of Pseudoalteromonas was found at the mid-shelf site (BD).

The bacteria OTUs and PSIB found on natural substrate were correlated to the environmental parameters at the three sites (correlation of most abundant OTUs in Figure 9).

\section{DISCUSSION}

While analyzing BCC and coral recruitment at three small islands in the Spermonde Archipelago, differences were mainly seen between the inshore site (LL) and those further away $(B L+B D)$, reflecting differences in environmental parameters and water quality between these zones.

\section{Environmental Parameters}

The clear separation of the inshore island (LL) from the two others $(\mathrm{BL}+\mathrm{BD})$ by lower water quality (higher $\mathrm{PO}_{4}$, Chl. A, and SPM) confirms previous findings in the same area (Sawall et al., 2013; Plass-Johnson et al., 2015; Polónia et al., 2015). Since other studies determined that impacts from the coast reached much further during the wet season (Dec-May) (Polónia et al., 2015), different results could be expected during seasons different from our sampling period, where the impacts from the mainland were restricted to the inshore site (LL). No differences between the near-shore island compared to the mid-shelf island were seen in most parameters, which would reflect the differences in population density on these islands. Thus, the influences from the coast and Makassar with the Jene Berang river close by seem to have a higher impact on the water quality surrounding the islands than the human inhabitants of the islands themselves. 


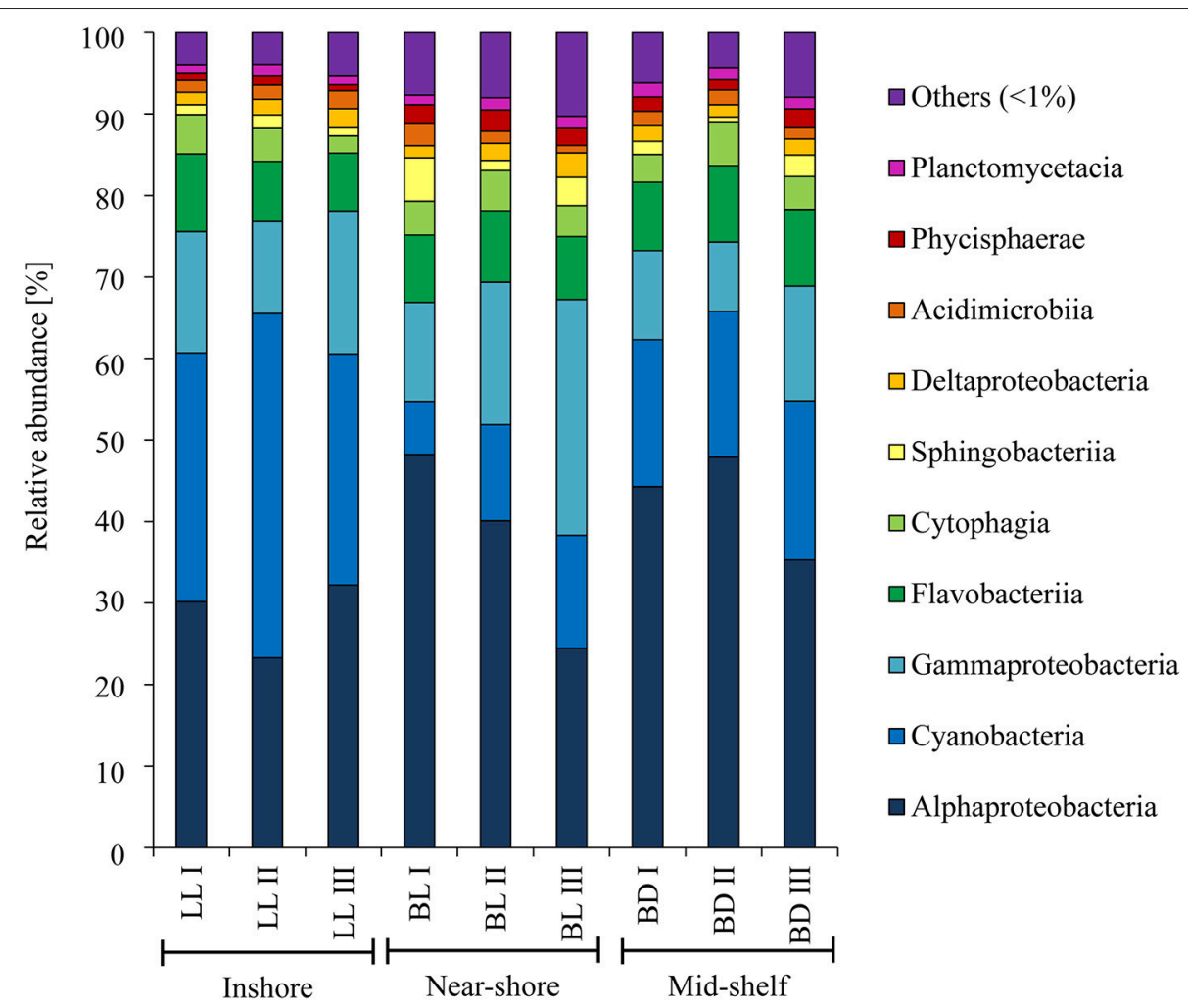

FIGURE 5 | Taxonomic composition at class-level of the bacterial communities on natural substrate. Shown are bacterial communities from three transects (roman numbers) at each of the three sites: inshore (LL), near-shore (BL), and mid-shelf (BD).

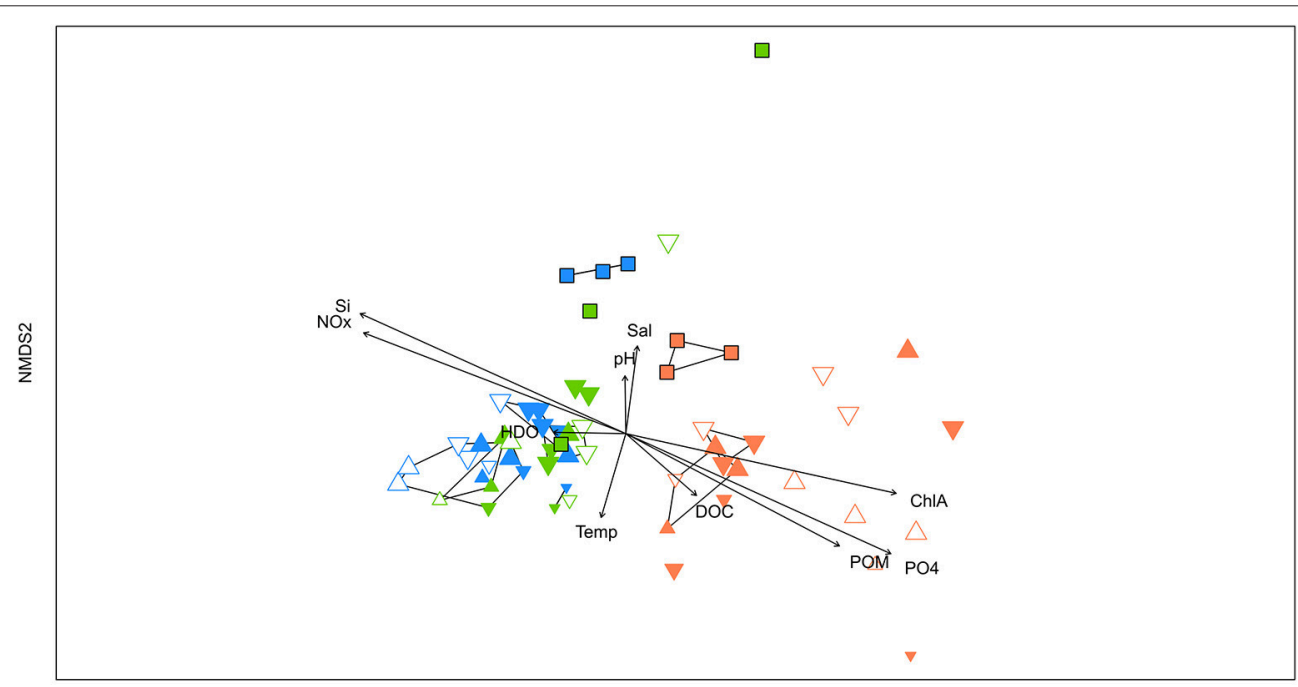

NMDS

FIGURE 6 | Non-metric multidimensional scaling (NMDS) plot of bacterial communities on natural and artificial substrates overlaid with environmental parameters (Si, silicate; NOx, Nitrate + nitrite; Sal, Salinity; HDO, dissolved oxygen; Temp, Temperature; DOC, dissolved organic carbon; POM, particulate organic matter; ChIA, chlorophyll a; PO4, phosphate). Sampling sites are shown by colors; with inshore (LL) = orange; near-shore (BL) = green; and mid-shelf (BD) = blue. Natural surfaces are represented by squares, artificial ceramic tiles by triangles, with size, filling, and orientation depending on deployment time, position on tile stack and orientation respectively. 


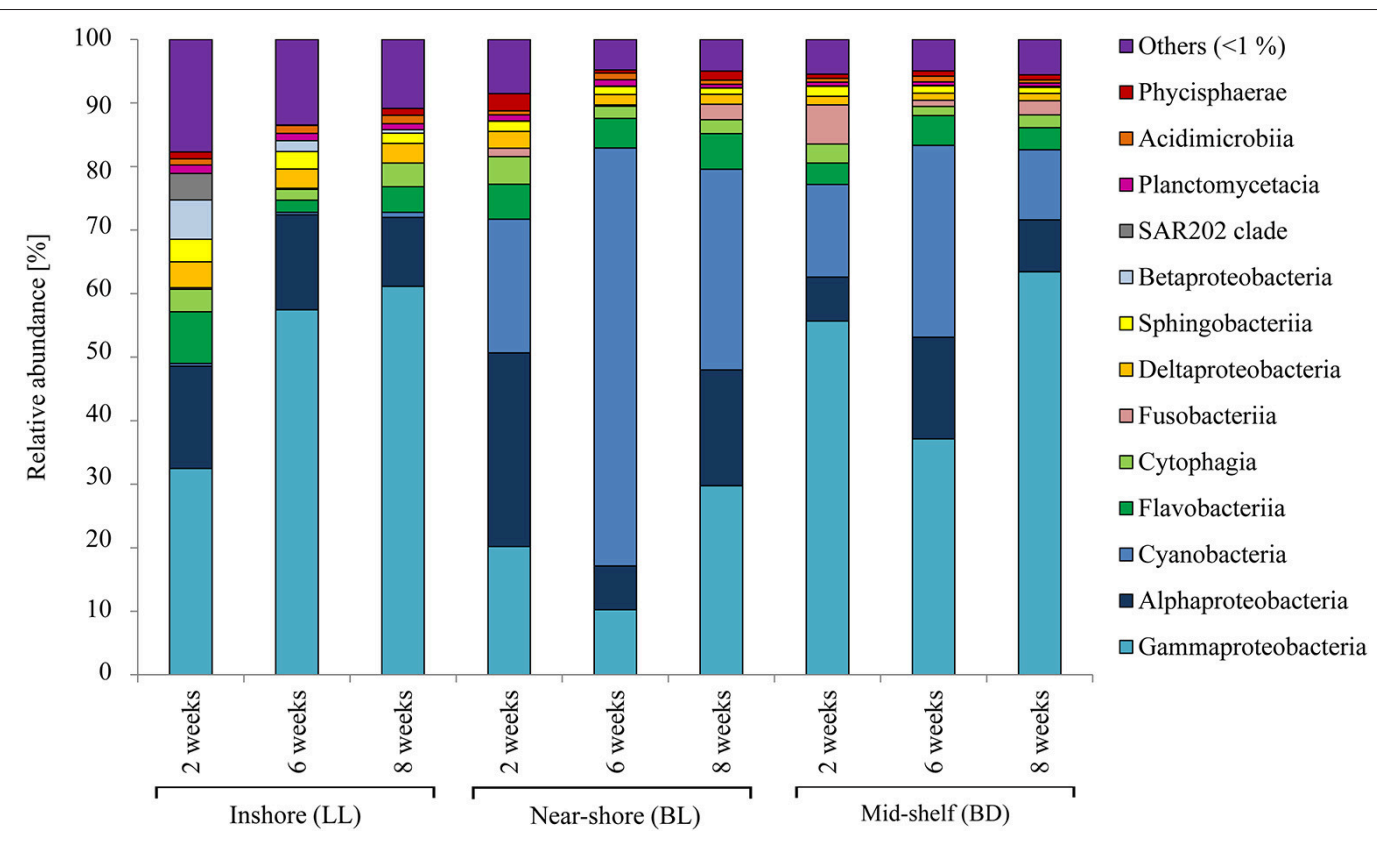

FIGURE 7 | Relative abundance of bacterial classes on artificial ceramic tiles. Bacterial communities were sampled on tiles after 2, 4, 6 , and 8 weeks exposure in the reef at three sites; inshore (LL), near-shore $(\mathrm{BL})$ and mid-shelf $(\mathrm{BD})$. Bacterial communities on lower tiles facing down are presented, for full range of all tiles see Figure S4

TABLE 2 | PERMANOVA results for the comparison of bacterial communities on OTU level between natural reef surface and artificial ceramic tiles at the three sites.

\begin{tabular}{lccc}
\hline & $\boldsymbol{R}^{\mathbf{2}}$ & $\boldsymbol{F}$ & $\boldsymbol{p}$-value \\
\hline Inshore (LL) & 0.42 & $1.80_{4,10}$ & 0.001 \\
Near-shore (BL) & 0.35 & $0.95_{4,7}$ & 0.553 \\
Mid-shelf (BD) & 0.55 & $2.78_{4,9}$ & 0.002 \\
\hline
\end{tabular}

TABLE 3 | PERMANOVA testing for an effect sampling site, exposure time, and tile surface on the bacterial community composition on artificial ceramic tiles.

\begin{tabular}{lcccc}
\hline Source of variation & $\boldsymbol{R}^{\mathbf{2}}$ & $\boldsymbol{F}$ & Df & $\boldsymbol{p}$ \\
\hline Site & 0.19574 & 7.2906 & 2.54 & 0.001 \\
Time & 0.10319 & 1.5374 & 5.54 & 0.004 \\
Surface & 0.05771 & 1.433 & 3.54 & 0.018 \\
Site:time & 0.18694 & 1.3926 & 10.54 & 0.002 \\
\hline
\end{tabular}

\section{Benthic Community}

Similar benthic community compositions as those observed here were found in previous studies of the same sites (Sawall et al., 2013; Plass-Johnson et al., 2015). At the same inshore island (LL) Sawall et al. (2013) found an increase in live hard coral cover from 10 to $18 \%$ between 2007 and 2009 . Our study indicates that hard coral cover has decreased considerably 5 years later, although this could also be due to slightly different survey locations in the reef. The low coral cover was similar to findings from 2012 and 2013 by Plass-Johnson et al. (2015) at the same coordinates. Alpha diversity of the benthic communities indicated a rich antifouling community at the inshore site and a rich coral community mid-shelf with an impoverished mix in between. High cover of coral rubble (38-56\%) was recorded at blast fishing impacted islands (Sawall et al., 2013), coinciding with the large amount of bare substrate and rubble found at the near-shore island (BL) during our study. These findings clearly indicate that in the Spermonde Archipelago reefs are objected to severe stresses leading to degradation of the ecosystem, which will also affect the reef fish communities (Plass-Johnson et al., 2017).

\section{Coral Recruitment}

The absence of coral recruits at the inshore site (LL) on any substrate, while recruitment was recorded several kilometers further away from the coast, has severe implications for the future of the reefs there. While recruitment of larvae was recorded at that island previously (Sawall et al., 2013) and live coral colonies still occurred there, our latest results indicate that successful recruitment may now be absent. Adverse environmental conditions can adversely affect reproduction, settlement and recruit survival of corals (Ritson-Williams et al., 2009). As the reproductive potential of local corals was not assessed in this study, it is not possible to discern the extent to which each of these factors shaped the observed patterns. Previous genetic studies in the Spermonde Archipelago indicate a limited exchange of coral larvae among inshore and nearshore islands (Knittweis et al., 2009), and it is likely that larvae produced at reefs further offshore may have been transported to the inshore site, but could not settle. In any case, the lack of recruitment poses a severe threat for the reefs at the inshore site in the future. Recruitment in the reefs at the other two islands was in the range of recruitment recorded previously in the area (Sawall et al., 2013) with $1.46 \pm 0.50$ spat per $100 \mathrm{~cm}^{2}$ over a 3 month 
period and also similar to other regions (Glassom et al., 2004; Salinas-de-León et al., 2011). Larvae that settled at either of the sites could also have originated from other reefs, however within the scope of this study it was not possible to differentiate between larvae that originated from the same reef and from elsewhere in the area.

In contrast to the findings in our study, previous authors recorded no differences in coral recruitment between natural reef substrate and artificial settlement substrates (Salinas-deLeón et al., 2011). Although there are no clear reports for coral spawning times in Spermonde (Sawall et al., 2013), strong indications are that it occurs between February and April (Salinas-de-León et al., 2013; Yusuf et al., 2013), thus slightly before our sampling period started. Larvae from this spawning period, especially mass-spawning species, would have already settled onto the reef, with a lower abundance of mass-spawned larvae in the surrounding waters during tile deployment. However, that does not fully explain why differences between the substrates were only found at one of the sites (BD), and further studies are necessary to determine the factors responsible.

It is noteworthy that when differences in coral recruitment between natural and artificial substrate were detected (at the midshelf site), there also were differences in BCC, or conversely no changes were observed in either of the two (at the near-shore site), further indicating the role of BCCs as an additional factor in the recruitment of coral larvae.

The clear preference of most of the recruits for downwardfacing tile surfaces has been observed in other studies as well (Maida et al., 1994; Sawall et al., 2013), and is most likely caused by grazing, higher light intensities facilitating algal growth, and higher sedimentation rates on the exposed upper sides. The numbers of coral recruitment on artificial settlement tiles is comparable to those in other studies from Sulawesi (Ferse et al., 2013; Sawall et al., 2013), however the proportion of Pocilloporidae was higher during this study (Maida et al., 1994; Sawall et al., 2013). Differences in larvae recruitment depending on substrate type have been reported for several artificial substrates (Baird et al., 2003; Burt et al., 2009) and the microstructure of substrates can increase spat survival (Nozawa, 2008), thus also causing different records of recruit numbers.

The increasing number of coral recruits at the mid-shelf site (BD) over the sampling period indicates a constant supply of coral larvae in the water column. This is supported by the high amount of larvae from brooding pocilloporid corals, which reproduce continuously, on the artificial tiles. At the near-shore site however, the highest numbers of coral recruits were recorded within the first weeks of deployment of the artificial substrates. Compared to this first phase of recruitment, numbers of coral recruits on the tiles decreased afterwards, with the exception of one of the frames where it remained constant. This could indicate a higher impact of the full moon or a spawning event at the beginning of the sampling period (Salinas-de-León et al., 2013; Yusuf et al., 2013) at the near-shore site as well. However, since coral recruits at that site also mostly comprised pocilloporids, other factors such as currents or post-settlement mortalities are more likely to have played a role in this temporal settlement pattern, but could not be investigated during our study.

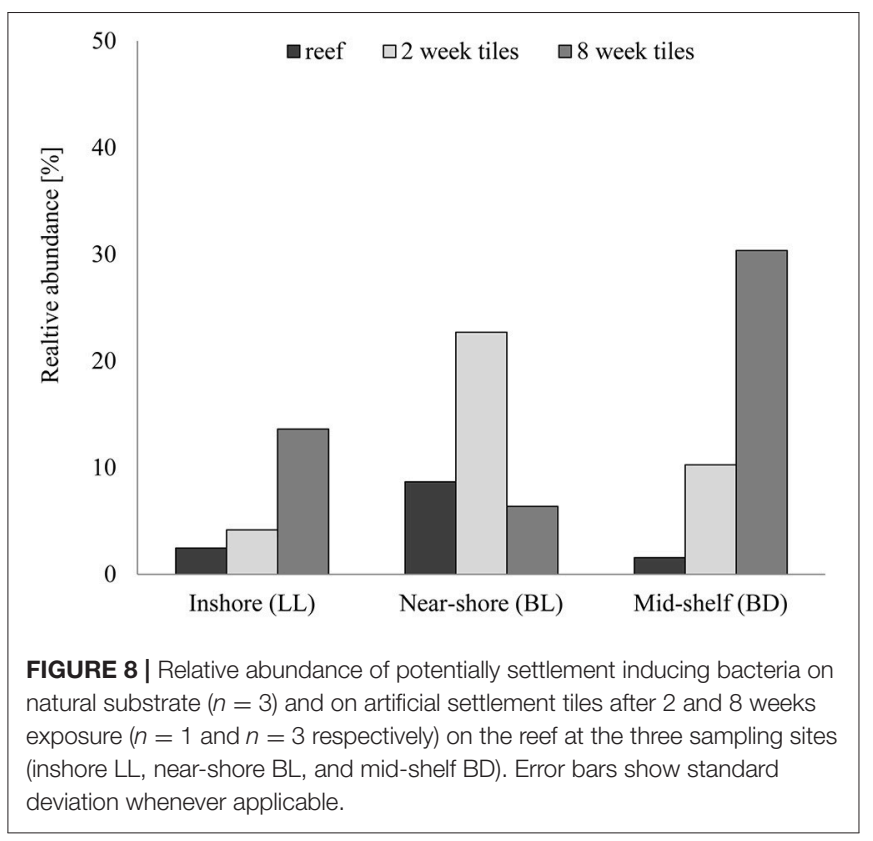

\section{Bacterial Communities}

The BCC found were similar to those in coral reef sediments at the Great Barrier Reef, composed of many Proteobacteria in addition to Cyanobacteria and several other classes (Uthicke and McGuire, 2007). Similar most abundant taxa were also among the most abundant on the surfaces of crustose coralline algae, CCA (Sneed et al., 2015). Cyanobacteria, which were found in highest numbers at the inshore site (LL), are often an indicator for bad water quality and eutrophic conditions (Agawina et al., 2003; Paerl et al., 2011) and may inhibit coral recruitment (Charpy et al., 2012), while Alphaproteobacteria, which had the lowest abundance at the inshore site, are often associated with more oligotrophic systems (Yin et al., 2013) and were found to be dominant on CCA surfaces, where their decrease was shown to reduce coral larvae settlement (Webster et al., 2011). These findings corroborate the assumption that the environmental conditions at the inshore site, which was most affected by anthropogenic impacts from nearby Makassar, accommodate a certain BCC accustomed to these conditions. This difference in BCC between the inshore site and the others was similar to the observed difference in water quality. Shifts from autotrophic to heterotrophic and sulfur- reducing bacteria with higher nutrient levels were previously reported in the same area (Sawall et al., 2012). BCC from rock surfaces in this study were correlated with site-specific characteristics of environmental parameters, similar to findings on BCC in sediments in the same area, which also correlated with water quality (Polónia et al., 2015). Although anthropogenic impact cannot be validated as the only cause for the differences in water quality and the patterns in BCC, the results from this study are strong indicators for the important role of these influences. However, as natural and anthropogenic terrestrial influences on water quality in the Spermonde Archipelago are more marked during the wet season (Sawall et al., 2012), stronger effects of gradients in 


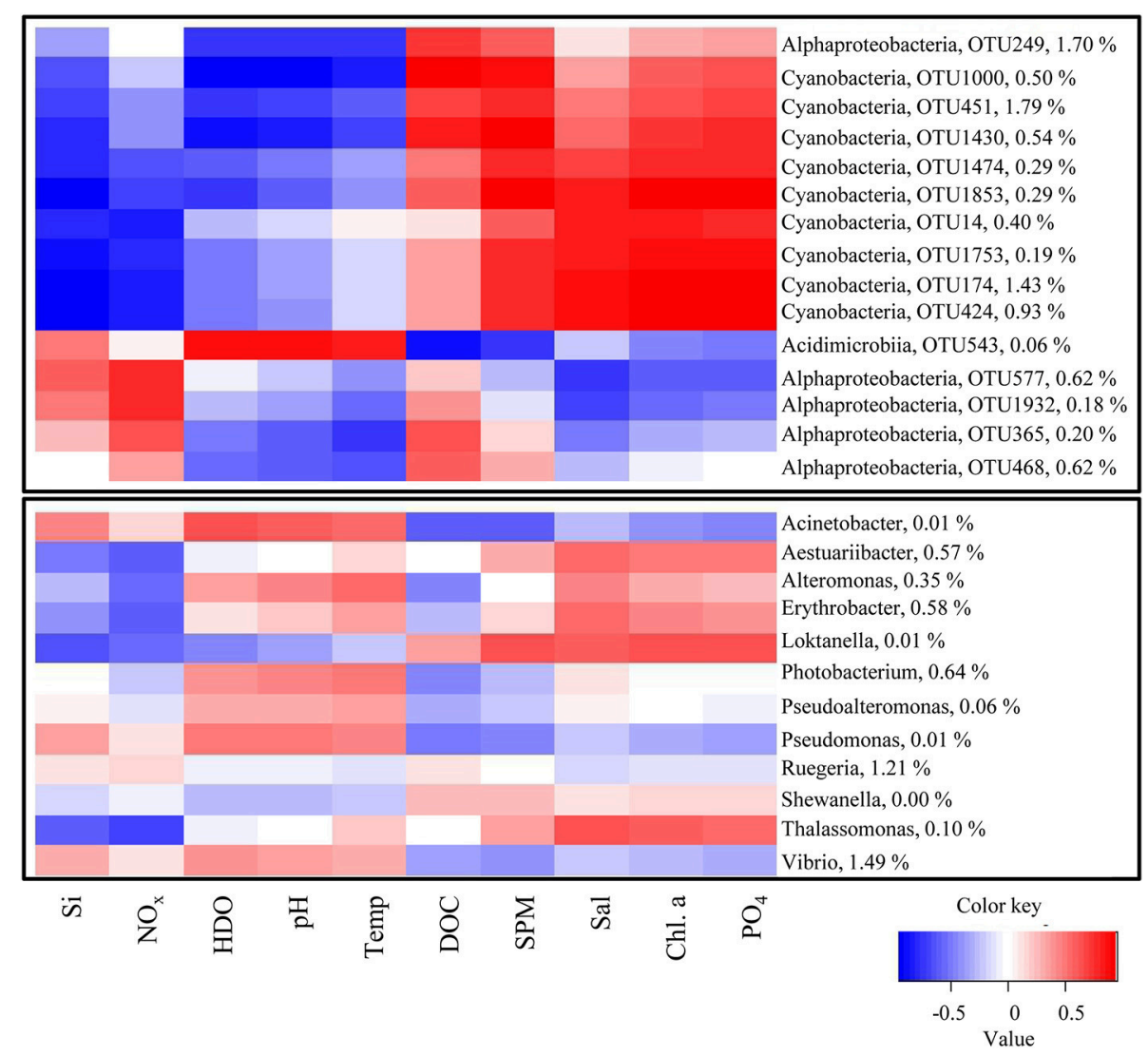

FIGURE 9 | Heatmap showing correlation of bacterial OTUs to environmental parameters. Top panel shows most abundant bacteria, lower panel shows PSIB. Environmental parameters measured were silicate (Si), nitrite/nitrate ( $\mathrm{NO}_{\mathrm{x}}$ ), dissolved oxygen (HDO), pH, temperature, dissolved organic carbon (DOC), suspended particulate matter (SPM), salinity (Sal), chlorophyll a (Chl a), and phosphate $\left(\mathrm{PO}_{4}\right)$. Relative abundance within all samples of the respective OTUs is given with the OTU label.

water quality on BCC would be expected at other sampling times.

In terms of bacterial communities, the ceramic tiles were a good imitation of the reef substrate at the near-shore site (BL), as BCC on the artificial substrates was similar to those on natural reef surfaces. However, at the two other sites significant differences between the two substrate types were recorded. This indicates a fast colonization of new substrates in the reef by opportunistic bacteria, while the establishment of stable communities, adapted to site-specific conditions, requires longer time periods than observed during this study. These differences between sites suggest that it would be beneficial for studies on BCC on artificial substrates to assess the validity of their findings by comparison to natural substrates, which is rarely done.

The higher abundance of PSIB on artificial substrates compared to natural reef surface could be due to the different surface materials or the fact that different seed populations of bacteria occupied the newly available space there compared to those that had led to the established reef communities. Furthermore, the genus Vibrio is included in the PSIB, which includes some species with potentially settlement inducing properties (Huggett et al., 2006; Tran and Hadfield, 2011), but also a high number of pathogens (Ben-Haim et al., 2003; Sussman et al., 2008), which could not be differentiated with the resolution of identification available in this study. The high abundance of PSIB at the near-shore site (BL) during the first 2 weeks and the decrease thereafter was mirrored by the high number of coral recruits in the beginning of the sampling period and decreasing numbers during the rest of the 2 months period. At the midshelf site (BD), the abundance of PSIB steadily increased with increasing exposure in the reef, as did the number of coral recruits. To validate the role of BCC in the settlement process of coral larvae however, an even closer look at the PSIB would be necessary.

\section{CONCLUSIONS}

The findings of this study underline several factors that need to be considered in evaluations of future reef management strategies. While no clear correlation between recruitment of larvae and BCC could be determined, this study showed that both are altered by habitat and environmental conditions. At 
the small inshore island off Makassar, with the combined impact of unfavorable water quality and low coral cover, the recruitment of coral larvae was significantly impaired. This potentially leads to a further decrease in coral cover and could cause a shift toward algae or soft coral dominated benthic reef communities there, which could have significant implications for the local human population depending on the reefs for their livelihoods. Despite strong local anthropogenic influence at the near-shore island $(\mathrm{BL})$ the recruitment of coral larvae was still plentiful and similar to the less impacted mid-shelf island (BD). This raises hope that as long as water quality is in a range suitable for corals and destructive disturbances are reduced, the reefs around this island may still have a good chance of recovery although coral cover at the moment is lower than at the mid-shelf island. Observed differences in BCC were mirrored by differences in coral recruitment. As BCC is known to change quickly in response to changing environmental conditions, in particular water quality, this indicates the potential for knock-on effects on coral larvae settlement. However, while the present study provided an indication of potential links between anthropogenically altered water quality, BCC and coral recruitment on different substrates, the study design did not permit conclusive evidence for the nature of such connections and the relative importance of anthropogenic compared to natural environmental factors. Further studies are needed to conclusively assess the links between these factors and predict what effects future changes in water quality and climate will have for the reefs surrounding the small islands in Spermonde and elsewhere.

\section{REFERENCES}

Agawina, N. S. R., Duartea, C. M., Agustí, S., and McManus, L. (2003). Abundance, biomass and growth rates of Synechococcus sp. in a tropical coastal ecosystem (Philippines, South China Sea). Estuar. Coast. Shelf. S 56, 493-502. doi: 10.1016/S0272-7714(02)00200-7

Andrews, S. (2011). FastQC-A Quality Control Tool for High Throughput Sequence Data. Babraham Bioinformatics. Available online at: http://www. bioinformatics.babraham.ac.uk/projects/fastqc/

Arnold, S. N., Steneck, R. S., and Mumby, P. J. (2010). Running the gauntlet: inhibitory effects of algal turfs on the processes of coral recruitment. Mar. Ecol. Prog. Ser. 414, 91-105. doi: 10.3354/meps08724

Babcock, R. C., Baird, A. H., Piromvaragorn, S., Thomson, D. P., and Willis, B. L. (2003). Identification of scleractinian coral recruits from Indo-Pacific reefs. Zool. Stud. 42, 211-226. Available online at: http://zoolstud.sinica.edu. tw/Journals/42.1/211.pdf

Baird, A. H., Babcock, R. C., and Mundy, C. P. (2003). Habitat selection by larvae influences the depth distribution of six common coral species. Mar. Ecol. Prog. Ser. 252, 289-293. doi: 10.3354/meps252289

Baird, A. H., Salih, A., and Trevor-Jones, A. (2006). Fluorescence census techniques for the early detection of coral recruits. Coral Reefs 25, 73-76. doi: 10.1007/s00338-005-0072-7

Bates, D., Maechler, M., Bolker, B., and Walker, S. (2015). Fitting linear mixedeffects models using lme4. J. Stat. Softw. 67, 1-48. doi: 10.18637/jss.v067.i01

Baum, G., Januar, H. I., Ferse, S. C. A., and Kunzmann, A. (2015). Local and regional impacts of pollution on coral reefs along the thousand islands north of the Megacity Jakarta, Indonesia. PLoS ONE 10:e138271. doi: 10.1371/journal.pone.0138271

Ben-Haim, Y., Zicherman-Keren, M., and Rosenberg, E. (2003). Temperatureregulated bleaching and lysis of the coral Pocillopora damicornis by the

\section{AUTHOR CONTRIBUTIONS}

This study was designed by $\mathrm{PK}, \mathrm{HK}, \mathrm{AG}, \mathrm{SF}$, and AK, with fieldwork planned by PK, HK, AG, SF, ML, YA, and AK. Data were collected by $\mathrm{PK}, \mathrm{HK}, \mathrm{AG}$, and $\mathrm{ML}$ and analyzed by all authors. Statistical analysis in $\mathrm{R}$ was conducted by $\mathrm{PK}, \mathrm{HK}$, and $\mathrm{CH}$. The manuscript was written with contributions from all authors and approved for publication by all authors.

\section{ACKNOWLEDGMENTS}

We would like to thank our Indonesian partners at LIPI-P2O, Universitas Hasanuddin and the staff of the Barrang Lompo field station for technical support during the field work. Our gratitude further goes to the technicians at the ZMT Bremen for assistance with the chemical analyses. This study was funded by the German Federal Ministry of Education and Research $(\mathrm{BMBF})$ within the project SPICE III (Science for the Protection of Indonesian Coastal marine Ecosystems, grant No. 03F0641A). The publication of this article was partly funded by the Open Access Fund of the Leibniz Association. A part of the study was presented during the 13th International Coral Reef Symposium, 19.-24.06.2016, and published in the conference proceedings.

\section{SUPPLEMENTARY MATERIAL}

The Supplementary Material for this article can be found online at: http://journal.frontiersin.org/article/10.3389/fmars. 2017.00270/full\#supplementary-material

novel pathogen Vibrio coralliilyticus. Appl. Environ. Microb. 69, 4236-4242. doi: 10.1128/AEM.69.7.4236-4242.2003

Benjamini, Y., and Hochberg, Y. (1995). Controlling the false discovery rate: a practical and powerful approach to multiple testing. J. ER. Statist. Soc. B 57, 289-300.

Bolger, A. M., Lohse, M., and Usadel, B. (2014). Trimmomatic: a flexible trimmer for illumina sequence data. Bioinformatics 30, 2114-2120. doi: 10.1093/bioinformatics/btu170

Bourne, D. G., and Webster, N. S. (2013). "Coral reef bacterial communities" in The Prokaryotes-Prokaryotic Communities and Ecophysiology, eds E. Rosenberg, E. F. DeLong, S. Lory, E. Stackebrandt, and F. Thompson (Berlin: Springer), 163-187.

BPS Kota Makassar (2010). Makassar Dalam Angka. Makassar: DU Areso.

Burke, L., Reytar, K., Spalding, M. D., and Perry, A. (2012). Reefs at Risk Revisited in the Coral Triangle. Washington, DC: World Resources Institute.

Burt, J., Bartholomew, A., Bauman, A., Saif, A., and Sale, P. F. (2009). Coral recruitment and early benthic community development on several materials used in the construction of artificial reefs and breakwaters. J. Exp. Mar. Biol. Ecol. 373, 72-78. doi: 10.1016/j.jembe.2009.03.009

Carpenter, K. E., Abrar, M., Aeby, G., Aronson, R. B., Banks, S., Bruckner, A., et al. (2008). One-third of reef-building corals face elevated extinction risk from climate change and local impacts. Science 321, 560-563. doi: 10.1126/science.1159196

Charpy, L., Casareto, B. E., Langlade, M. J., and Suzuki, Y. (2012). Cyanobacteria in coral reef ecosystems: a review. J. Mar. Biol. 2012:259571. doi: 10.1155/2012/259571

Chung, H. C., Lee, O. O., Huang, Y.-L., Mok, S. Y., Kolter, R., and Qian, P.Y. (2010). Bacterial community succession and chemical profiles of subtidal biofilms in relation to larval settlement of the polychaete Hydroides elegans. ISME J. 4, 817-828. doi: 10.1038/ismej.2009.157 
Cinner, J. (2014). Coral reef livelihoods. Curr. Opin. Environ. Sustain. 7, 65-71. doi: 10.1016/j.cosust.2013.11.025

Cleary, D. F., Becking, L. E., de Voogd, N. J., Renema, W., de Beer, M., van Soest, R. W., et al. (2005). Variation in the diversity and composition of benthic taxa as a function of distance offshore, depth and exposure in the Spermonde Archipelago, Indonesia. Estuar. Coast. Shelf. S 65, 557-570. doi: $10.1016 /$ j.ecss.2005.06.025

Edinger, E. N., Jompa, J., Limmon, G. V., Widjatmoko, W., and Risk, M. J. (1998). Reef degradation and coral biodiversity in Indonesia: effects of land-based pollution, destructive fishing practices and changes over time. Mar. Poll. Bull. 36, 617-630. doi: 10.1016/S0025-326X(98)00047-2

English, S., Wilkinson, C., and Baker, V. (1997). Survey Manual for Tropical Marine Resources. Townsville, QLD: Australian Institute of Marine Science.

Fernandes, D. A., Reid, J., Macklaim, M. J., McMurrough, T. A., Edgell, D. R., and Gloor, B., G (2014). Unifying the analysis of high-throughput sequencing datasets: characterizing RNA-seq, $16 \mathrm{~S}$ rRNA gene sequencing and selective growth experiments by compositional data analysis. Microbiome 2:15. doi: 10.1186/2049-2618-2-15

Ferse, S. C. A., Nugues, M. M., Romatzki, S. B. C., and Kunzmann, A. (2013). Examining the use of mass transplantation of brooding and spawning corals to support natural coral recruitment in Sulawesi/ Indonesia. Restor. Ecol. 21, 745-754. doi: 10.1111/rec.12004

Fournier, D. A., Skaug, H. J., Ancheta, J., Ianelli, J., Magnusson, A., Maunder, M., et al. (2012). AD Model Builder: using automatic differentiation for statistical inference of highly parameterized complex nonlinear models. Optim. Methods Softw. 27, 233-249. doi: 10.1080/10556788.2011.597854

Giraudoux, P. (2016). pgirmess: Data Analysis in Ecology. R Package Version 1.6.4. Available online at: https://CRAN.R-project.org/package=pgirmess

Glassom, D., Zakai, D., and Chadwick-Furmann, N. A. (2004). Coral recruitment: a spatio-temporal analysis along the coastline of Eilat, northern Red Sea. Mar. Biol. 144, 641-651. doi: 10.1007/s00227-003-1243-0

Hadfield, M. G. (2011). Biofilms and marine Invertebrate larvae: what bacteria produce that larvae use to choose settlement sites. Annu. Rev. Mar. Sci. 3, 453-470. doi: 10.1146/annurev-marine-120709-142753

Halpern, B. S., Walbridge, S., Selkoe, K. A., Kappel, C. V., Micheli, F., D’Agrosa, C., et al. (2008). A global map of human impact on marine ecosystems. Science 319, 948-952. doi: 10.1126/science.1149345

Harrison, P. L. (2011). "Sexual reproduction of scleractinian corals," in Coral reefs an Ecosystem in Transition, eds Z. Dubinsky and N. Stambler (Dordrecht; Heidelberg; London; New York, NY: Springer), 59-85.

Heyward, A. J., and Negri, A. P. (1999). Natural inducers for coral larval metamorphosis. Coral Reefs 18, 273-279. doi: 10.1007/s003380050193

Huggett, M. J., Williamson, J. E., de Nys, R., Kjelleberg, S., and Steinberg, P. D. (2006). Larval settlement of the common Australian sea urchin Heliocidaris erythrogramma in response to bacteria from the surface of coralline algae. Oecologia 149, 604-619. doi: 10.1007/s00442-006-0470-8

Keough, M. J., and Downes, B. J. (1982). Recruitment of marine invertebrates: the role of active larval choices and early mortality. Oecologia 54, 348-352. doi: 10.1007/BF00380003

Klindworth, A., Pruesse, E., Schweer, T., Peplies, J., Quast, C., Horn, M., et al. (2013). Evaluation of general 16S ribosomal RNA gene PCR primers for classical and next-generation sequencing-based diversity studies. Nucleic Acids Res. 41:e1. doi: 10.1093/nar/gks808

Knittweis, L., Kraemer, W., Timm, J., and Kochzius, M. (2009). Genetic structure of Heliofungia actiniformis (Scleractinia: Fungiidae) populations in the IndoMalay Archipelago: implications for live coral trade management efforts. Conserv. Genet. 10, 241-249. doi: 10.1007/s10592-008-9566-5

Kohler, K. E., and Gill, S. M. (2006). Coral Point Count with Excel extensions (CPCe): a visual basic program for the determination of coral and substrate coverage using random point count methodology. Comput. Geosci. 32, 1259-1269. doi: 10.1016/j.cageo.2005.11.009

Lau, S. C., Thiyagarajan, V., Cheung, S. C., and Qian, P. Y. (2005). Roles of bacterial community composition in biofilms as a mediator for larval settlement of three marine invertebrates. Aquat. Microb. Ecol. 38, 41-51. doi: 10.3354/ame038041

Mahé, F., Rognes, T., Quince, C., de Vargas, C., and Dunthorn, M. (2014). Swarm: robust and fast clustering method for amplicon-based studies. PeerJ 2:e593. doi: $10.7717 /$ peerj.593
Maida, M., Coll, J. C., and Sammarco, P. W. (1994). Shedding new light on scleractinian coral recruitment. J. Exp. Mar. Biol. Ecol. 180, 189-202. doi: 10.1016/0022-0981(94)90066-3

Meyer-Reil, L. A., and Köster, M. (2000). Eutrophication of marine waters: effects on benthic microbial communities. Mar. Poll. Bull. 41, 255-263. doi: 10.1016/S0025-326X(00)00114-4

Morris, E. K., Caruso, T., Buscot, F., Fischer, M., Hancock, C., Maier, T. S., et al. (2014). Choosing and using diversity indices: insights for ecological application from the German biodiversity exploratories. Ecol. Evol. 4, 3514-3524. doi: $10.1002 /$ ece3.1155

Munday, P. L. (2004). Habitat loss, resource specialization, and extinction on coral reefs. Glob. Change Biol. 10, 1642-1647. doi: 10.1111/j.1365-2486.2004.00839.x

Negri, A. P., Webster, N. S., Hill, R. T., and Heyward, A. J. (2001). Metamorphosis of broadcast spawning corals in response to bacteria isolated from crustose algae. Mar. Ecol. Prog. Ser. 223, 121-131. doi: 10.3354/meps223121

Nozawa, Y. (2008). Micro-crevice structure enhances coral spat survivorship. J. Exp. Mar. Biol. Ecol. 367, 127-130. doi: 10.1016/j.jembe.2008.09.004

Oksanen, J., Blanchet, F. G., Kindt, R., Legendre, P., Minchin, P. R., O’Hara, R. B., et al. (2016). vegan: Community Ecology Package. R package version 2.3-4. Available online at: https://CRAN.R-project.org/package=vegan

Paerl, H. W., Hall, N. S., and Calandrino, E. S. (2011). Controlling harmful cyanobacterial blooms in a world experiencing anthropogenic and climatic- induced change. Sci. Tot. Environ. 409, 1739-1745. doi: 10.1016/j.scitotenv.2011.02.001

Pet-Soede, L., and Erdmann, M. V. (1998). Blast fishing in Soutwest Sulawesi, Indonesia. Naga ICLARM Q. 21, 4-9.

Plass-Johnson, J. G., Ferse, S. C. A., Bednarz, V. N., Gärdes, A., Heiden, J. P., Lukman, M., et al. (2017). Spatio-temporal patterns in the coral reef communities of the Spermonde Archipelago, 2012-2014, II: fish assemblages display structured variation related to benthic condition. Front. Mar. Sci.

Plass-Johnson, J. G., Heiden, J. P., Abu, N., Lukman, M., and Teichberg, M. (2015). Experimental analysis of the effects of consumer exclusion on recruitment and succession of a coral reef system along a water quality gradient in the Spermonde Archipelago, Indonesia. Coral Reefs 35, 229-243. doi: 10.1007/s00338-015-1369-9

Polónia, A. R. M., Cleary, D. C. R., de Voogd, N. J., Renema, W., Hoeksema, B. W., Martins, A., et al. (2015). Habitat and water quality variables as predictors of community composition in an Indonesian coral reef: a multitaxon study in the Spermonde Archipelago. Sci. Tot. Environ. 537, 139-151. doi: 10.1016/j.scitotenv.2015.07.102

Price, N. (2010). Habitat selection, facilitation and biotic settlement cues affect distribution and performance of coral recruits in French Polynesia. Oecologia 163, 747-758. doi: 10.1007/s00442-010-1578-4

Pruesse, E., Peplies, J., and Glöckner, F. O. (2012). SINA: accurate high-throughput multiple sequence alignment of ribosomal RNA genes. Bioinformatics 28, 1823-1829. doi: 10.1093/bioinformatics/bts252

Qian, P. Y., and Dahms, H. U. (2009). "A triangle model: Environmental changes affect biofilms that affect larval settlement" in Marine and Industrial Biofouling, eds H. C. Flemming, P. S. Murthy, R. Venkatesan, and K. Cooksey (Berlin: Springer), 315-328.

Qian, P. Y., Thiyagarajan, V., Lau, S. C. K., and Cheung, S. C. K. (2003). Relationship between bacterial community profile in biofilm and attachment of the acorn barnacle Balanus amphitrite. Aquat. Microb. Ecol. 33, 225-237. doi: $10.3354 / \mathrm{ame} 033225$

Quast, C., Pruesse, E., Yilmaz, P., Gerken, J., Schweer, T., Yarza, P., et al. (2013). The SILVA ribosomal RNA gene database project: improved data processing and web-based tools. Nucl. Acids. Res. 41, D590-D596. doi: 10.1093/nar/gks1219

R Core Team. (2016). R: A Language and Environment for Statistical Computing. Vienna: R Foundation for Statistical Computing. Available online at: URL https://www.R-project.org/.

Richmond, R. H., and Wolanski, E. (2011). "Coral research: past efforts and future horizons," in Coral Reefs: An Ecosystem in Transition, eds Z. Dubinsky and N. Stambler (Dordrecht; Heidelberg; London, UK; New York, NY: Springer), 3-10.

Ritson-Williams, R., Arnold, S. N., Fogarty, N. D., Steneck, R. S., Vermeij, M. J. A., and Paul, V. J. (2009). New perspectives on ecological mechanisms affecting coral recruitment on reefs. Smithson. Contrib. Mar. Sci. 38, 437-457. doi: $10.5479 /$ si.01960768.38.437 
Salinas-de-León, P., Costales-Carrera, A., Zeljkovic, S., Smith, D. J., and Bell, J. J. (2011). Scleractinian settlement patterns to natural cleared reef substrata and artificial settlement panels on an Indonesian coral reef. Estuar. Coast. Shelf $S$ 93, 80-85. doi: 10.1016/j.ecss.2011.02.016

Salinas-de-León, P., Dryden, C., Smith, D. J., and Bell, J. J. (2013). Temporal and spatial variability in coral recruitment on two Indonesian coral reefs: consistently lower recruitment to a degraded reef. Mar. Biol. 160, 97-105. doi: 10.1007/s00227-012-2066-7

Sawall, Y., Jompa, J., Litaay, M., Maddusila, A., and Richter, C. (2013). Coral recruitment and potential recovery of eutrophied and blast fishing impacted reefs in Spermonde Archipelago, Indonesia. Mar. Poll. Bull. 74, 374-382. doi: 10.1016/j.marpolbul.2013.06.022

Sawall, Y., Richter, C., and Ramette, A. (2012). Effects of eutrophication, seasonality and macrofouling on the diversity of bacterial biofilms in equatorial coral reefs. PLoS ONE 7:e39951. doi: 10.1371/journal.pone.0039951

Schmidt-Roach, S., Kunzmann, A., and Arbizu, P. M. (2008). In situ observation of coral recruitment using fluorescence census techniques. J. Exp. Mar. Biol. Ecol. 367, 37-40. doi: 10.1016/j.jembe.2008.08.012

Sharp, K. H., and Ritchie, K. B. (2012). Multi-partner interactions in corals in the face of climate change. Biol. Bull. 223, 66-77. doi: 10.1086/BBLv223n1p66

Siegel, S., and Castellan, N. J. (1988). Non Parametric Statistics for the Behavioral Sciences. New York, NY: MacGraw Hill Int.

Sneed, J. M., Ritson-Williams, R., and Paul, V. J. (2015). Crustose coralline algae species host distinct bacterial assemblages on their surfaces. ISME J. 9, 2527-2536. doi: 10.1038/ismej.2015.67

Sneed, J. M., Sharp, K. H., Ritchie, K. B., and Paul, V. J. (2014). The chemical cue tetrabromopyrolle from a biofilm bacterium induces settlement of multiple Caribbean corals. P. R. Soc. B 281:20133086. doi: 10.1098/rspb.2013.3086

Stanley, G. D. Jr. (2003). The evolution of modern corals and their early history. Earth Sci. Rev. 60, 195-225. doi: 10.1016/S0012-8252(02)00104-6

Sussman, M., Willis, B. L., Victor, S., and Bourne, D. G. (2008). Coral pathogens identified for White Syndrome (WS) epizootics in the Indo-Pacific. PLoS ONE 3:e2393. doi: 10.1371/journal.pone.0002393

Tebben, J., Motti, C. A., Siboni, N., Tapiolas, D. M., Negri, A. P., Schupp, P. J., et al. (2015). Chemical mediation of coral larval settlement by crustose coralline algae. Sci. Rep. 5:10803. doi: 10.1038/srep 10803

Tebben, J., Tapiolas, D. M., Motti, C. A., Abrego, D., Negri, A. P., Blackall, L. L., et al. (2011). Induction of larval metamorphosis of the coral Acropora millepora by tetrabromopyrrole isolated from a Pseudoalteromonas bacterium. PLoS ONE 6:e19082. doi: 10.1371/journal.pone. 0019082

Teichberg, M., Wild, C., Bednarz, V. N., Kegler, H. F., Lukman, M., Gärdes, A., et al. (2017). Spatio-temporal patterns in coral reef communities of the Spermonde
Archipelago, 2012-2014, I: comprehensive reef monitoring reveals two indices that reflect changes in reef health. Front. Mar. Sci.

Tran, C., and Hadfield, M. G. (2011). Larvae of Pocillopora damicornis settle and metamorphose in response to surface biofilm bacteria. Mar. Ecol. Prog. Ser. 433, 85-96. doi: 10.3354/meps09192

Uthicke, S., and McGuire, K. (2007). Bacterial communities in Great Barrier Reef calcareous sediments: contrasting $16 \mathrm{~S}$ rDNA libraries from nearshore and outer shelf reefs. Estuar. Coast. Shelf 72, 188-200. doi: 10.1016/j.ecss.2006.10.017

Veron, J. E. N. (2000). Corals of the World-Volume 1, Townsville, QLD: Australian Institute of Marine Science and CRR Qld Pty Ltd.

Warnes, G. R., Bolker, B., Bonebakker, L., Gentleman, R., Huber, W., Liaw, A., et al. (2016). gplots: Various R Programming Tools for Plotting Data. R Package Version 3.0.1. Available online at: https://CRAN.R-project.org/package=gplots

Webster, N. S., Smith, L. D., Heyward, A. J., Watts, J. E. M., Webb, R. I., Blackall, L. L., et al. (2004). Metamorphosis of a scleractinian coral in response to microbial biofilms. Appl. Environ. Microb. 70, 1213-1221. doi: 10.1128/AEM.70.2.1213-1221.2004

Webster, N. S., Soo, R., Cobb, P., and Negri, A. P. (2011). Elevated seawater temperature causes a microbial shift on crustose coralline algae with implications for the recruitment of coral larvae. ISME J. 5, 759-770. doi: 10.1038/ismej.2010.152

Yin, Q., Fu, B., Li, B., Shi, X., Inagaki, F., and Zhang, X.-H. (2013). Spatial variations in microbial community composition in surface seawater from the ultra-oligotrophic center to rim of the South Pacific Gyre. PLoS ONE 8:e55148. doi: 10.1371/journal.pone.0055148

Yusuf, S., Jompa, J., Zamani, N. P., and Junior, M. Z. (2013). Reproduction pattern and multispecific spawning of Acropora spp. In Spermonde Islands reef, Indonesia. Ilmu Kelautan 18, 172-178. doi: 10.14710/ik.ijms.18.3.172-178

Zhang, J., Kobert, K., Flouri, T., and Stamatakis, A. (2014). PEAR: a fast and accurate illumina paired-end reAd mergeR. Bioinformatics 30, 614-620. doi: 10.1093/bioinformatics/btt593

Conflict of Interest Statement: The authors declare that the research was conducted in the absence of any commercial or financial relationships that could be construed as a potential conflict of interest.

Copyright (C) 2017 Kegler, Kegler, Gärdes, Ferse, Lukman, Alfiansah, Hassenrück and Kunzmann. This is an open-access article distributed under the terms of the Creative Commons Attribution License (CC BY). The use, distribution or reproduction in other forums is permitted, provided the original author(s) or licensor are credited and that the original publication in this journal is cited, in accordance with accepted academic practice. No use, distribution or reproduction is permitted which does not comply with these terms. 